\title{
Living with the Trilemma Constraint: Relative Trilemma Policy Divergence, Crises, and Output Losses for Developing Countries
}

\author{
Joshua Aizenman* \\ University of Southern California and NBER \\ Hiro Ito** \\ Portland State University
}

April 2014

\begin{abstract}
This paper investigates the potential impacts of the degree of divergence in open macroeconomic policies in the context of the trilemma hypothesis. Using an index that measures the relative policy divergence among the three trilemma policy choices, namely monetary independence, exchange rate stability, and financial openness, we find that emerging market countries have adopted trilemma policy combinations with the least degree of relative policy divergence in the last fifteen years. We find that a developing or emerging market country with a higher degree of relative policy divergence is more likely to experience a currency or debt crisis. However, a developing or emerging market country with a higher degree of relative policy divergence tends to experience smaller output losses when it experiences a currency or banking crisis. Latin American crisis countries tended to reduce their financial integration in the aftermath of a crisis, while this is not the case for the Asian crisis countries. The Asian crisis countries tended to reduce the degree of relative policy divergence in the aftermath of the crisis, probably aiming at macroeconomic policies that are less prone to crises. The degree of relative policy divergence is affected by past crisis experiences -- countries that experienced currency crisis or a currency-banking twin crisis tend to adopt a policy combination with a smaller degree of policy divergence.
\end{abstract}

JEL Classification Nos.: F31, F36, F41, O24

Keywords: Impossible trinity; international reserves; financial liberalization; financial crisis; exchange rate regime.

\footnotetext{
* Aizenman: Dockson Chair in Economics and International Relations, University of Southern California, University Park, Los Angeles, CA 90089-0043. Phone: +1-213-740-4066. Email: aizenman@ usc.edu. ** Ito (corresponding author): Department of Economics, Portland State University, 1721 SW Broadway, Portland, OR 97201. Tel/Fax: +1-503-725-3930/3945. Email: ito@pdx.edu
} 


\section{Introduction}

Managing policies in an economic turbulence is a challenging task, especially in the world with highly integrated financial markets. History is full of episodes where monetary regimes ends abruptly, involving financial crises or turbulence, as we have witnessed in the collapse of the Bretton Woods system in the early 1970s or in the financial crises many emerging market economies experienced in the 1980s and 1990s. No matter what forms of international monetary systems or regimes replace the old ones, countries end up adopting a combination of three policy goals: monetary independence, exchange rate stability, and financial openness, with different degrees of attainment in each. That is, a powerful hypothesis called the "impossible trinity," or the "trilemma" dictates open macro policy management. Countries may choose any two, but not all, of the three policy goals to their full extent, or adopt a combination of intermediate degrees of all of the three policy goals.

Theory and empirical evidence tell us that each one of the three trilemma policy choices can be a double-edged sword as recognized by a significant amount of recent literature. ${ }^{1}$ To make the matter more complicated, the effect of each policy choice can differ depending on what other policy choice it is paired with. For example, exchange rate stability can be destabilizing when paired with financial openness, yet be stabilizing if paired with greater monetary autonomy. Furthermore, countries rarely face the stark polarized binary choices as often envisioned by policy makers and researchers.

Obviously, different combinations of the three policies have different macroeconomic effects. A key question is, while being constrained by the rule of the trilemma, how can a country's open policy combination affect its macroeconomic performance, especially in terms of avoiding traumatic economic turbulence such as financial crises?

\footnotetext{
${ }^{1}$ See Aizenman and Ito (2013) for a list of papers that examines the issues pertaining to the three trilemma policies.
} 
Against this backdrop, we evaluate the patterns of the degree of divergence among the three trilemma policies in the last four decades, especially focusing on its implications for crisis economies. In Section 3, we implement a series of empirical exercises to examine the impact of the degree of trilemma relative policy divergence on the likelihood of the onset of a currency, banking, and debt crisis, and also on the output losses from these different types of crises. In Section 4 , we focus on the endogenous nature of the degree of relative policy divergence and how it can be affected by past crisis experiences. In Section 5, we summarize the main findings of the paper.

\section{Divergence of the Trilemma Policy Choices}

\subsection{Why Does the Extent of Relative Policy Divergence Matter?}

While there are only three kinds of polarized policy combinations among the three trilemma policies, once intermediate levels for each policy are allowed, there can exist an infinite number of open macro policy combinations. Some countries implement partial financial integration while trying to retain control over exchange rate movement as well as monetary policy autonomy. This sort of "middle-ground convergence," has been a characteristic of emerging market countries (EMG) in recent decades as Aizenman, Chinn, and Ito (2013) have shown.

By adopting such converged policy combinations, these countries may have been trying to dampen the negative effects that may arise from adopting polarized policy regimes. Interestingly, the period when EMG's middle convergence started becoming more evident coincides with the time when some of these economies began accumulating sizable international reserves (IR), probably trying to buffer the trade-off arising from the trilemma. 
A key question is how the location within the trilemma triangle affects macroeconomic performance, especially when we focus on the risk of experiencing a financial crisis. Furthermore, such correlations may not be merely a function of the country's own macroeconomic policies. Rather, a country's open macro policies need to be evaluated in a greater context, compared with policies adopted by other countries. ${ }^{2}$

Anecdotally, countries tended to adopt monetary regimes prevalent in other countries, making the types of monetary regimes across countries correlated with each other. When many countries tend to adopt similar monetary regimes, such a herding behavior tends to create externalities, lowering the cost of a country following such a global or regional trend, or the "mean behavior." Conversely, herding behavior in arranging monetary regimes may also raise the opportunity cost of deviating from it, unless the country that deviates from the "mean behavior" is well-equipped with healthy fundamentals or solid institutions including wellfunctioning financial markets. Hence, it is important to evaluate the combinations of open macro policies in a global context or in comparison to other countries.

\subsection{Measure of relative policy divergence and Its Patterns}

In order to gage how much convergence or divergence is taking place among the three trilemma policy choices in a global context, we construct the "measure of divergence" in the triad policies by using the "trilemma indexes" introduced by Aizenman, Chinn, and Ito (2010, 2013).

The trilemma indexes measure the degree of achievement in each of the three policy choices for more than 170 economies from 1970 through $2010 .{ }^{3}$ The monetary independence index (MI) is based on the correlation of a country's interest rates with the base country's interest

\footnotetext{
${ }^{2}$ For example, a fixed exchange rate regime must have different effects on the economy depending on whether or not most other countries also adopt fixed exchange rate regimes as they did during the Bretton Woods period.

${ }^{3}$ The indexes are available at http://web.pdx.edu/ ito/trilemma indexes.htm.
} 
rate. The index for exchange rate stability (ERS) is an invert of exchange rate volatility, i.e., standard deviations of the monthly rate of depreciation, using the exchange rate between the home and base economies. The degree of financial integration is measured by the Chinn-Ito (2006, 2008) capital controls index (KAOPEN). ${ }^{4}$

Using these indexes, we define the "measure of relative policy divergence" as below:

$$
d_{i t}=\sqrt{\left(M I \_r_{i t}-1\right)^{2}+\left(E R S \_r_{i t}-1\right)^{2}+\left(K A O P E N \_r_{i t}-1\right)^{2}}
$$

where $X_{-} r_{i t}=\frac{X_{i t}}{\overline{X_{t}}}$ for $X=M I, E R S$, and $K A O P E N$, and $\overline{X_{t}}$ is cross-country average of $X$ in year $t^{5,6}$ By definition, $d_{i t}$ is a geometric mean of three dimensions of the Trilemma variable of country $i$ at time $t$ from the prevailing average choices, reflecting the relative divergence of the country's policies from the vector $\left\langle\overline{M I_{t}}, \overline{E R S_{t}}, \overline{K A O P E N_{t}}>\right.$. For the review of the long-run trends of $d$, refer to Aizenman and Ito (2012 and 2013).

\section{Behavior of $d$ around the Time of a Crisis}

Let us observe the behavior of the measure of policy dispersion around the time of a financial crisis. Figures 1-3 show the development of the cross-country average of the degree of relative policy divergence $(d)$ for different subsamples of countries for currency, banking, and debt crises, respectively, over the period from three years before the first year of the crisis

\footnotetext{
${ }^{4}$ Refer to Aizenman, et al. (2013), and the Trilemma website for the details of construction of the indexes.

${ }^{5}$ The cross country average $\left(\bar{X}_{t}\right)$ is the sample average of $\mathrm{X}$ including both industrialized and developing countries for year $t$.

${ }^{6}$ One could argue that if the extent of the three trilemma policy choices are linearly related as theoretically predicted, the above formula for $d$ does not have to contain all the three indexes - it would need only any two of the three trilemma indexes. However, we do not assume the linearity too strictly, i.e., the linearity does not have to hold every single year. In other words, we assume that there is some room for policy choices to deviate from the trilemma constraint. In fact, policy makers sometimes intentionally or unintentionally challenge the constraint of the trilemma by implementing a policy combination that is not consistent with the trilemma hypothesis. Before aborting the fixed exchange rate arrangement for the Thai baht, Thai policy makers attempted to challenge the trilemma by pursuing both greater monetary independence and exchange rate stability without imposing capital controls. Also, holding a massive amount of IR may allow countries to deviate from the constraint of the trilemma in the short run.
} 
through three years after it (i.e., $\left.\left[t_{0}-3, t_{0}+3\right]\right) .{ }^{7}$ In each figure, Panel (a) shows the development of the subsample averages of $d$ for IDC, LDC, and EMG. ${ }^{8}$ Panel (b) shows the development of the averages of $d$ for the crisis countries that experienced positive output losses as a result of a crisis, and Panel (c) shows those which experienced output gains (i.e., output losses <0). ${ }^{9}$

In all three kinds of crises, there is a hump shape of development for $d$ around the first year of the crisis, while the peak occurs at the first year for currency crisis $\left(t_{0}\right)$; a year after the onset of a banking crisis $\left(t_{0}+1\right)$; and a year before the onset of a debt crisis $\left(t_{0}-1\right)$. In the cases of currency and banking crises, if the crisis involves output losses, the measure of relative policy divergence tends to stay at high levels during the first and second years of the crisis. In the case of the debt crisis, countries that did not experience output losses, experience a peak in $d$ in the year before the onset of the crisis. This may imply that these countries could avoid output losses by preemptively implementing stabilization measures that end up raising the degree of policy divergence.

It is harder to generalize the movement of $d$ for debt crisis countries. Panel (c) shows that those debt crisis countries that experience a peak in $d$ prior to the onset of a crisis tend to be the ones that experience output losses, which tend to be contrary to the case of currency or banking crises countries.

\section{Empirical Analysis}

\footnotetext{
${ }^{7}$ The methods for identifying the three types of crises are explained in the working paper version of this article (Aizenman and Ito, 2013).

${ }^{8}$ The emerging market countries (EMGs) are defined as the countries classified as either emerging or frontier during the period of 1980-1997 by the International Financial Corporation plus Hong Kong and Singapore.

${ }^{9}$ As we explain later, output losses are defined as the cumulative sum of the differences between actual and trend real GDP over the four-year period (i.e., $\left[t_{0}, t_{0}+3\right]$. The trend real GDP is based on HP-filtered real GDP series over the twenty-year-long pre-crisis period $\left[t_{0}-20, t_{0}-1\right]$. Based on whether the cumulative sum is positive or negative, a crisis is defined to involve output losses or gains. In a sense, the existence of output losses is based on "output losses in ex post," not strictly as of the first year of the crisis.
} 


\subsection{Probability of Crisis Occurrence}

We now estimate the probability of different types of crises to examine whether and to what extent the degree of relative policy divergence affects the likelihood of a currency, banking, or debt crisis.

For each type of the crisis, we assign the value of one to a binary variable $y_{t}$ when country $i$ experiences the onset of a crisis in year $t$, and zero, otherwise.$^{10} \mathrm{We}$ hypothesize the probability that a crisis will occur, $\operatorname{Pr}\left(y_{t}=1\right)$, is a function of a vector of characteristics associated with observations in year $t$, or $X_{t}$, and the parameter vector $\beta$, with the control variables in X lagged one year to avoid endogeneity issues. Using the panel data composed of more than 100 countries for the period $1970-2010$, the log of the following function is maximized with respect to the unknown parameters through non-linear maximum likelihood.

$$
\ln L(\beta)=\sum_{i=1}^{m}\left[y_{t} \ln F\left(\beta^{\prime} X_{t}\right)+\left(1-y_{t}\right) \ln \left(1-F\left(\beta^{\prime} X_{t}\right)\right)\right]
$$

where $m$ indicates the number of countries times the number of observations for each country and the function $\mathrm{F}($.$) is the standardized normal distribution.$

The following variables are included in the characteristics vector $X_{t}$. The choice of the variables is based on the past literature, except for the ones related to the degree of trilemma policy convergence.

Variables included in the estimation:

Relative income to the U.S. - Countries' per capita income levels from the Penn World Table (PWT) are normalized as a ratio to the U.S. per capita income level. International reserves (IR) holding - IR excluding gold as a ratio to GDP .

\footnotetext{
${ }^{10} \mathrm{We}$ only focus on the onset of a crisis, that is, the first year of the crisis. This means that we do not investigate the persistence of a crisis situation if it lasts longer than one year.
} 
Per capita Output growth - The growth rate of GDP per capita (in local currency).

Private credit growth - The change (first-difference) in the ratio of private credit creation to GDP.

Net Debt inflows - The ratio of (external debt liabilities- external debt assets) to GDP. The original data are from Lane and Milesi-Ferretti (2007 and updates).

Gross external financial exposure - The ratio of (total external assets + total external liabilities) to GDP(from the Lane and Milesi-Ferretti dataset), included as the ratio in the estimation as deviations from the five-year average. After the global financial crisis, in addition to net capital flows or investment positions, gross capital flows have been pointed as potential destabilizing factors. ${ }^{11}$

Real exchange rate overvaluation - It is defined as deviations from a fitted trend in the real exchange rate. The real exchange rate is calculated using the exchange rate between country $i$ and its base country (in the sense of Aizenman, et al., 2011), and the CPI of the two countries. Higher values of this variable indicate the real exchange rate value is lower, i.e., appreciated, than its time trend.

Exchange rate stability (ERS) and Financial openness (KAOPEN) - Both are from the trilemma indexes of Aizenman, Chinn, and Ito (2012).

Triad Relative policy divergence Measure - The aforementioned measure of triad relative policy divergence $d_{i t}$ is included.

\footnotetext{
${ }^{11}$ See Borio and Disyatat (2011), Obstfeld (2012a, b), Bruno and Shin (2012) for the argument on how gross external financial exposure matters for financial and economic stability. However, it must be noted that gross external financial exposure may also mean a higher level of ability to diversify risk, which may work as a stabilizing fact.
} 
Standard deviations of the Triad Relative policy divergence Measure - The standard deviations of the above $d_{i t}$ over five years from $\mathrm{t}-5$ through $t-1$ are included to examine the impact of the stability level of the trilemma policy combinations.

Other crises - The dummies for the other types of crises that occur either concurrently $(t)$ or in the previous year $(t-1)$ are also included.

Contagion - To see the impact of other crises in the same geographical region, we also include a variable that represents the effect of regional contagion. The variable to be included is defined as:

$$
\text { Contagion }_{i, t}^{n}=\sum_{\substack{j=1 \\ j \neq i}}^{P_{K}} \omega_{j_{K}} \cdot C D_{i, t}^{n}
$$

$C D^{n}{ }_{i, t}$ is a crisis dummy for type $n$ crisis (i.e., currency, banking, or debt). $\omega_{j_{k}}$ is the weight based on GDP in PPP for country $\mathrm{j}(j \neq i)$ in region $K$. Hence, the variable Contagion $^{n}$ is the weighted sum of the dummy variables for the countries in the region country $i$ belongs to, excluding the weighted dummy of country $i$ itself. ${ }^{12}$ The basic assumptions are that the more countries in the same geographical region experience crises, the more likely it is for country $i$ to experience a crisis, and that the contagious effect is larger for bigger economies.

We apply the above probit estimation model to the full sample that includes both industrialized and developing countries, the sample of industrialized countries (IDC), the sample of developing countries (LDC), and a subsample of emerging market countries (EMG).

\subsection{Estimation Results - Measure of Policy Divergence as a Determinants of Crisis}

\section{Occurrences}

\footnotetext{
${ }^{12}$ The regions we consider are: West hemisphere (i.e., North and South Americans), East and Southeast Asia and the Pacific, South Asia, Europe (including both Western, Eastern, and Central Europe), and Sub-Saharan Africa, Middle East and North Africa.
} 
In Table 1, we report the results of the probit estimation in terms of the marginal effects of the explanatory variables for when the variables take mean values (except for the dummy variables). ${ }^{13}$ While most of the explanatory variables turn out to be qualitatively consistent with the findings in the literature, though statistical significance varies by the sample group, we focus our observations on the findings of the behavior of $d .^{14}$

In the currency crisis estimation, interestingly, we find that developing or emerging market countries that pursue more divergent triad policies from the global trend (as of a year prior to the crisis) are more likely to experience a currency crisis although the opposite impact is found for industrialized countries while the degree of triad policy stability does not matter for any of the subsamples. The positive impact of a greater relative policy divergence on the likelihood of a currency crisis occurring among developing countries may mean that it involves some opportunity cost for these economies to adopt a combination of open macro policies that deviates from the global trend, which may explain why many developing economies have tended in recent years to either adopt triad policies with middle-ground convergence, or hold a massive amount of international reserves, or both. Contrarily, for industrialized countries, a combination of diverse policies might help countries avoid experiencing a currency crisis, though its effect is only marginally significant. This may suggest that industrialized countries can afford to pursue a higher degree of relative policy divergence with their established policy credibility.

In the banking crisis estimation, nether the degree of triad relative policy divergence nor the degree of instability of the triad policies affects the probability of bank crisis occurrence for any of the subsamples. Among the three types of financial crises, banking crisis seems to be the

\footnotetext{
${ }^{13}$ In the estimation for debt crisis, the estimation results for the full or IDC sample are not reported because there is no debt crisis data for industrialized countries in our sample period (that ends in 2010).

${ }^{14}$ See Kaminsky and Reinhart (1999), Kaminsky et al. (1998), Glick and Hutchison (2001), and Kaminsky (2003) for currency crisis, and Aizenman and Noy (2012), Demirgüç-Kunt and Detragiache (1998), von Hagen and Ho (2007), Joyce (2011), and Duttagupta and Cashin (2011) for banking crisis.
} 
most weakly linked with the extent of triad policy divergence. One possibility for the weak link is that a certain choice of a monetary regime affects other macroeconomic conditions in a way that these conditions would have more direct impacts on the financial system. In the estimation result for the LDC group (column (7)) in Table 1, credit growth and financial exposure are positive contributors to the likelihood of an occurrence of a banking crisis. We can suspect that triad policy divergence may possibly affect the probability of a banking crisis occurrence but only through these two variables. Capital can flow to markets that are distinctively different from other markets. In the literature, it has been argued that a policy regime with high degrees of exchange rate stability and financial openness would often make an economy more conducive to influx of capital flows, eventually experiencing a boom and bust cycle. That tendency can be stronger if a certain market or economy adopts a monetary regime that is more distinct from the global trend - which can be captured by $d$ - compared to when many others adopt a similar monetary regime (e.g., the Bretton Woods system). In sum, the effect of triad policy divergence could be masked by changes in macroeconomic conditions that might have a bigger impact on the likelihood of a banking crisis.

Like in the case of currency crisis, a higher degree of triad policy divergence tends to lead to debt crisis. If a country pursues a distinctly more divergent triad policy compared to the global trend, that may cause stress on the economy. Possibly, investors would start suspecting the sustainability of the country's policy management and therefore question the future ability of repaying the debt. Such stress may become self-fulfilling and eventually force the country to experience a debt crisis. The instability of the triad policy combination also matters though only with marginal significance. That also implies that unstable open macro policy management may 
weaken the credibility of the country in terms of its policy management and debt sustainability, and lead investors to attack speculatively the country's sovereign bond markets.

\subsection{The Determinants of Output Losses from Crises}

Now that we know that developing countries with greater relative policy divergence are more exposed to the risk of experiencing either currency or debt crisis, we examine whether and to what extent the degree of relative policy divergence affects output losses that arise once a crisis does break out. To measure output losses accompanying a crisis, we follow the method used in Laeven and Valencia $(2008,2010,2012)$ and cumulatively sum the differences between actual and trend real GDP over the four-year period that starts in the first year of a crisis period (i.e., $\left.\left[t_{0}, t_{0}+3\right]\right)$. The trend real GDP for the output loss estimation is a counterfactual path of real GDP based on Hodrick-Prescott (HP) filtering over the twenty-year-long pre-crisis period $\left[t_{0}-\right.$ $\left.20, t_{0}-1\right] .^{15}$

We continue to use most of the candidate explanatory variables we used for the probit analysis, but sample the observations differently. ${ }^{16}$ Instead of running estimations on annual panel data, we only sample crisis episodes and implement event-study estimations. That will reduce the number of observations significantly.

The right-hand-side variables such as relative income, per capita GDP growth rate, IR/GDP holding, real exchange rate overvaluation, exchange rate stability (ERS), financial openness $(K A O P E N)$, and credit growth are, again, included as of $t_{0^{-}} 1$, i.e., a year before the onset of a crisis, unless mentioned otherwise. We also include the dummy for the existence of the

\footnotetext{
${ }^{15}$ Refer to Aizenman and Ito (2013) for more details on how to measure the size of output losses accompanying a crisis and its summary statistics.

${ }^{16}$ We do not include the dummies for contagion of crises due to the lack of theoretical rationale.
} 
deposit insurance system as of $t_{0^{-}}-1$ as well as the dummies for the two other types crises in the estimation to examine the impact of twin crises. ${ }^{17,18}$

Tables 2 reports the estimation results for different samples: the full sample, and the LDC and EMG subsamples. We focus on the variable for trilemma relative policy divergence $(d)$ as of the year before the onset of a crisis $\left(t_{0}-1\right)$. Due to the small sample size and resultant weakness in the estimation results, we do not report or discuss the estimation results for the subsample of industrialized countries.

Among the explanatory variables, again, most of the findings are qualitatively consistent with other studies though there are a few exceptions. The variable for IR holding has the negative sign, but it is only significant for industrialized countries (not reported), which is somewhat odd considering their better accessibility to international financial markets. A country that enters a currency or debt crisis with real exchange rate appreciation tends to experience larger output losses. The more externally indebted it is, the larger output losses an emerging market economy would face once it experiences a currency or banking crisis. Interestingly, (de jure) financial openness seems to contribute to larger output losses especially for an emerging market economy that experiences a currency crisis. This finding is consistent with the oft-argued belief that financial liberalization can be harmful for developing, especially middle-income, countries (such as Kaminsky and Schmukler, 2002). Only the twin crisis with the combination of currency and banking crises involves larger output losses than solo crises. Deposit insurance systems are helpful in reducing the size of output losses for both banking and debt crises. ${ }^{19}$

\footnotetext{
${ }^{17}$ For the deposit insurance dummy, we use the data from the dataset compiled by Demirgüç-Kunt, et al. (2005). We also update the data and expand the scope of country coverage by using the information from the website of the International Association of Deposit Insurers (IADI) and other national governmental agencies in charge of deposit insurance.

${ }^{18}$ The dummies for the other types of crises take the value of one when they occur in $t_{0}-1, t_{0}$, or $t_{0}+1$.

${ }^{19}$ Trade openness is found to be persistently insignificant, and therefore, is dropped from the estimation. The dummies for commodity exporters (i.e., countries that are either or both of major food and fuel exporters) and
} 
As for trilemma policy divergence, its level (i.e., $d$ as of $t_{0}-1$ ) does reduce the output losses arising from currency or banking crisis for developing and emerging market countries, though its impact is insignificant for the banking crisis estimations. This finding can be somewhat contradictory to the previous probit estimation results that a higher value of $d$ increases the probability of an onset of currency crisis (and debt crisis). How do we reconcile these ostensibly contradictory results, especially in the case of currency crisis?

Figures 4 and 5 help us solve the "puzzle" regarding the role of the trilemma policy divergence. These figures show that the averages of deviations from the world mean of $M I, E R S$, and $K A O P E N$, i.e., $\_r=M I / \overline{M I}, E R S \_r=E R S / \overline{E R S}$, and $K A O \_r=K A O / \overline{K A O}$ for the countries that experience either currency or banking crisis. These deviations are used to calculate $d$ (Eq. 1). For each figure, the top row displays the average deviations from the world mean of the three trilemma indexes for the crisis episodes that accompanied output losses whereas the bottom row displays for those without output losses.

We can make several interesting observations from these figures.

- Not surprisingly, currency crisis countries reduce the level of exchange rate stability. But those crisis countries with higher levels of exchange rate stability as of the pre-crisis period tend to experience larger output losses.

- Countries "fight" currency crisis by retaining greater monetary independence; the level of monetary independence tends to be higher in the year before the crisis occurrence. Those currency crisis countries which actively intervened with greater monetary independence in the year before the onset of the crisis tend not to experience output losses. That is true especially for emerging market countries. 
- Currency crisis does not affect financial openness, though countries with more open financial accounts tend to experience larger output losses.

- Some emerging market countries may implement capital controls in the years leading to the onset of a crisis, which may allow the countries to retain greater monetary independence while maintaining the level of exchange rate stability.

- In the case of banking crisis, the characteristics of monetary independence between crisis countries with and without output losses are opposite to the case of currency crisis. Countries with active interventions with greater monetary independence in the pre-crisis years end up experiencing output losses, possibly indicating that active interventions by the monetary authorities may create moral hazard among financial institutions. In such an environment, once a banking crisis occurs, a sudden contraction of credit could lead to a severe contraction of output. Conversely, those countries which avoid experiencing output losses exercise monetary independence once the crisis occurs (i.e., $t_{0}+1$ and $t_{0}+2$ ), mitigating credit constraint and thereby avoiding output contraction.

- The behavior of exchange rate stability among banking crisis countries is similar to the case of currency crisis.

- As was the case with currency crisis, more financially open countries tend to experience output losses. And once they do, emerging market countries tend to lower the level of financial openness.

So, what do these all mean? First, when developing countries face a situation with pressure for market corrections, they often try to fight the amounting pressure by retaining greater monetary independence. They do so while trying to both retain stability in the exchange rate movement and maintain the level of financial openness. However, such an effort forces the 
economy to face even greater pressure because the attempts to preemptively stabilize the economy without changing the other open macro policies could challenge the constraint of the trilemma. Hence, the action of fighting the pressure for market corrections itself would lead the country to experience a currency crisis, which is essentially a self-fulfilling prophecy.

Second, although the action of fighting market pressure with greater monetary independence itself causes the country to experience a crisis, it could also help reduce the level of output losses once the crisis occurs. By trying to achieve a higher "latitude" in the level of monetary independence, once a currency crisis occurs, the crisis country's monetary independence falls rapidly, but the higher "latitude" its monetary independence falls from, the smaller degree of currency devaluation is needed - see the panels for MI and ERS in the middle row of Figure 4. Hence, a country that lowers the level of monetary independence from a higher "latitude," tends to experience a smaller degree of disruption in its exchange rate stability, making the disturbance in the financial sector smaller and thereby the output cost smaller. ${ }^{20}$

What do we learn from these findings? First, there is no question that pursuing a policy combination that yields lower $d$ would be better because it reduces the probability of experiencing a crisis (especially for currency and debt crises). Second, a rational country aware of the risk that a policy combination that involves a higher $d$ could lead to a crisis could still implement such a policy combination, if it is necessary, so that it could end up experiencing smaller output losses even once a crisis does occur. In other words, by "causing" a crisis, the country may be able to "defuse" the negative impact of a crisis so that it could experience a crisis with smaller output losses.

\subsection{Further Analyses}

\footnotetext{
${ }^{20}$ This explanation is applicable especially when the country does not alter the extent of financial openness in the midst of a financial crisis as we observe in Figure 4.
} 
Asymmetry between Crises with Output Losses and Those with Output 'Gains'

A financial crisis does not necessarily lead to output losses; it can lead to output 'gains.' We wonder if there is any asymmetry between the case where a crisis involves output losses and the case where a crisis leads to output gains.

To examine the asymmetry, we modify our estimation exercise. Instead of having the dependent variable of output losses as a variable that can take both positive and negative values, we will have the dependent variable that shows either only output losses or output gains. That is, when we focus on the determinants of only output losses, we assign zeroes to the dependent variable if a crisis episode involves negative values for output losses (i.e., output gains). For the estimation on the determinants of output 'gains,' we assign zeroes to the dependent variable if a crisis episode involves positive values for output losses (i.e., output losses). In either case, because the dependent variable is bounded by zero, we will use the Tobit regression model. With the two sets of regression results, we will examine if there is any asymmetry between the output loss and gain estimations by comparing the estimated coefficients.

The regression results (not reported) show some asymmetrical effects on output losses and gains. While international reserves holding is found to increase output gains across the three types of crises, it does not have any (negative or loss-reducing) effect on output losses. Larger external debt would increase output losses arising from currency crisis, but it would not affect output gains. Credit growth would help increase output losses for currency or banking crisis, but it does not have any impact on output gains.

Interestingly, the degree of relative policy divergence contributes negatively to output losses in both currency and banking crises while it does not affect output gains. Hence, the 
degree of triad relative policy divergence is especially important when a country is experiencing output losses that accompany a currency or banking crisis.

\section{Regional d}

Considering that regional externality can arise in a way that policies implemented in a region affect the policies of other countries within the region, deviating from the regional trend may also possibly matter, which we now test whether that is true.

We reconstruct the measure of relative policy divergence, $d^{R}$, now against the averages of the three trilemma indexes for each of the regions: "North and South America," "Europe," "East and South Asia," "Middle-east and North Africa," and "Sub-Saharan Africa," and repeat the same estimation as we did in Table $2 .^{21}$

Overall, interestingly, we find the results are intact (not reported). Both the magnitude and the statistical significance of the estimates of $d^{R}$ are similar to what we found for $d$ in Table 2 . Hence, we conclude that relative policy divergence with respect to regional trends also affect the size of output losses, and therefore, that regional externality plays an important role.

\section{The Effect of Legal/Institutional Development}

If a crisis country is equipped with better institutions, such as more predictable legal systems, better-functioning bureaucracy, and more committed anti-corruption measures, the effect of open macro policy coordination may differ. Hence, better institutions should help a greater $d$ to reduce the size of output losses at the time of a crisis. To examine this, we include in the estimation a variable $L E G A L$ as a measure of general legal/institutional development, that is the first principal component of law and order $(L A O)$, bureaucratic quality $(B Q)$, and anti-

\footnotetext{
21 "Europe" includes Western, Central, and Eastern Europe. Here, $X_{-} r_{i t}=\frac{X_{i t}}{\overline{X_{t}}}$ in equation (1) is calculated with $\overline{X_{t}}$ representing the regional average of each of the trilemma indexes.
} 
corruption measures (CORRUPT), and its interaction term with $d .{ }^{22}$ We also test each of the component variables, i.e., $L A O, B Q$, and CORRUPT, in place of $L E G A L$ to investigate what is driving the effect of $L E G A L$.

We first note that, if a country equipped with more developed legal systems and institutions pursues a higher $d$, it tends to experience smaller output losses at the time of a currency crisis. The result is significant only for the LDC group and marginally significant for the EMG group.

Second, we find that bureaucratic quality is driving the results with $L E G A L$. The estimations with $B Q$ usually have the highest adjusted $R$-squared among the three types of estimations. Also, the estimate on the interaction between $B Q$ and $d$ is often significantly negative, though anticorruption measures also seem to matter for the LDCs with currency crisis. The Role of IMF Stabilization Programs

Another potential factor that may affect the size of output losses, possibly through trilemma policy coordination, is IMF's stabilization program. Hutchison (2003) showed that participating in an IMF stabilization program may help reduce output growth, though the participation following a currency crisis does not affect output growth. Similarly, Przeworski and Vreeland (2000) show the negative impact of IMF's stabilization programs as long as participating countries are remain under a program, though they could grow faster once they leave the program. Given this background, we look into the question of whether and to what extent the impact of relative policy divergence can differ if a country is under an IMF stabilization program.

\footnotetext{
${ }^{22} L A O, B Q$, and $C O R R U P T$ are extracted from the ICRG database. Higher values of these variables indicate better
} conditions. 
We include in the estimation a dummy that takes the value of one if country $i$ receives non-concessional loans from the IMF in the first year, or a year before, of a financial crisis. ${ }^{23} \mathrm{We}$ focus on the interaction with between the dummy and $d$.

Including the dummy and its interaction with $d$ does not change the results for currency and banking crisis (not reported). However, for both LDC and EMG countries that experienced a debt crisis, the interaction term has a significantly negative estimate while $d$ per se does not have a significant estimate. These results indicate that if a country that experiences a debt crisis is under an IMF's program for non-concessional loans and implements a policy coordination that involves a higher level of policy divergence, it could experience a smaller size of output losses. The Effects of Each Trilemma Index

We are also curious how each of the trilemma indexes, in terms of their deviations from the global trend, affects the size of output losses. In other words, we are interested in examining the relative importance of each of the trilemma indexes.

For that, we include in the estimation $a \frac{\left|M I_{i t}-\overline{M I_{t}}\right|}{\overline{M I_{t}}}+b \frac{\left|E R S_{i t}-\overline{E R S_{t}}\right|}{\overline{E R S_{t}}}+c \frac{\mid \text { KAOPEN }_{i t}-\overline{\text { KAOPEN }_{t}} \mid}{\overline{\text { AOOPEN }_{t}}}$ in place of $d$. The estimates $\hat{a}, \hat{b}$, and $\hat{c}$ should represent the weights on the three trilemma variables, $M I, E R S$, and $K A O P E N$, respectively. ${ }^{24}$ Since we have found that $d$ matters in the estimation for the output losses of a currency crisis, we conduct this exercise only for the output losses of currency crisis.

\footnotetext{
${ }^{23}$ We thank Joseph Joyce for providing us with the data on IMF's stabilization programs. "Non-concessional loan facilities" include EFF (Extended Fund Facility); FCL (Flexible Credit Facility); PLL (Precautionary and Liquidity Line (PLL); and SBA (Stand-By Arrangement). "Concessional loan facilities" include ECF (Extended Credit Facility); ESAF (Enhanced Structural Adjustment Facility); PRGF (Poverty Reduction and Growth Facility); RCF (Rapid Credit Facility); SAF (Structural Adjustment Facility); and SCF (Standby Credit Facility). For more details, refer to Joyce (2012).

${ }^{24}$ In the original measure $d$, we implicitly assumed equal weights for the three trilemma indexes (eq. (1)). We now relax such a constraint.
} 
The estimation results (not reported) indicate that, for all the samples, the signs of the estimated coefficients on the three absolute deviations are all negative, though only the EMG group has all of the deviations statistically significant. Among the three deviation variables, the estimate on $M I$ is significantly negative and its magnitude is the largest for all the samples, suggesting that monetary independence matters the most in terms of helping to reduce the size of output losses for an economy experiencing a currency crisis, a consistent result with Figure 4. The deviation of exchange rate stability from the global trend would matter as well - to almost the same extent as that of monetary independence in the case of emerging market countries. Financial openness seems to matter the least among the three variables; the magnitude of the estimate is usually the smallest for all the subsamples, and the estimate is statistically significant only for the EMG group.

\section{The Effect of in "Tranquil Times"}

What is the impact of $d$ when countries are not experiencing financial crisis, i.e., during the "tranquil" times? To examine this, we use the output gap as the dependent variable and restrict the sample only to include the observations when countries are not experiencing any of the three types of crises. ${ }^{25}$ To preserve parallelism for comparison, we base the choice of the explanatory variables on the previous estimation on output losses, but remove the variables for per capita income growth, IR holding, and the crisis dummies. We also include the first lag of the dependent variable. We report the results in Columns (1) through (3) of Table 3.

The variable of our focus, the measure of relative policy divergence $d_{(t-1)}$, is found to negatively affect output gaps during the tranquil times. This is an interesting contrast to the previous analysis; while a higher $d$ would help reduce the size of output losses at the time of a

\footnotetext{
${ }^{25}$ Output gap is measured by the difference between the actual real output series and the HP-filtered output trend. A positive output gap means the actual real output is greater than the HP-filtered trend.
} 
currency crisis, it would help decrease the output gap at the tranquil times. During the tranquil times, deviating from the global trend of open macro policies seems to entail some cost, which may be attributed to positive externality from policy coordination. However, once an economy experiences a crisis, deviating from the global trend will be necessary to reduce the output losses.

As we did previously, we examine the weights of contribution among the absolute deviations of the three trilemma indexes from the global trend. The results reported in Columns (4) through (6) of Table 3 show that, generally, the absolute deviations from the global trend are negative contributors to output gaps during the tranquil periods as we found in $d$. The magnitude of the contribution is the largest for the absolute deviations of ERS among the three variables, followed by those of $M I$ and $K A O P E N$, though the ranking of the latter two depends on the sample. This is in contrast to our previous analysis that showed the absolute deviations of $M I$ as the largest, negative contributor to the size of output losses (or positive contributor to accumulative output gaps) of a country experiencing currency crisis. As we discussed, this finding reflects the importance of monetary stabilization policy once there is a possibility of a currency crisis occurring. During the "tranquil" times, however, the deviations of the degree of exchange rate stability from the global trend is the largest, negative contributor to the size of output gaps. This finding is consistent with the anecdotal argument that it is costly for developing or emerging market countries to adopt their exchange rate policy that deviates from the global trend. ${ }^{26}$

\section{Endogeneity and the Determinants of the Degree of Trilemma Policy Divergence}

\footnotetext{
${ }^{26}$ Because we are referring to the absolute deviations of ERS from the global mean, it does not imply whether adopting a policy with greater or lower exchange rate stability is beneficial to output gaps.
} 
The hump shape of $d$ around the time of the onset of a crisis as we observed in the previous figures, or the trend that emerging market countries have reduced the level of $d$ in the aftermath of crises in the late 1990s suggest that $d$ itself can be endogenously affected by the experience of crises.

We can test the hypothesis that experiencing more crises would make countries tend to adopt more converged combinations of trilemma policies by implementing the following estimation:

$$
d_{i t}=\gamma_{0}+\gamma_{1} d_{i t-1}+Z_{i t}{ }^{\prime} \Gamma+\phi C R I S I S_{i(t-5 \mid t-1)}+\zeta_{i t}
$$

where $Z_{i t}$ is a vector of control variables that include relative income, IR holding, trade openness (the sum of exports and imports as a share of GDP), the share of $i$ 's economy in the world (based on current U.S. dollars), and the dummies for manufacturing exporters and the countries in the European Monetary Union (EMU). ${ }^{27}$ These variables are included contemporaneously, except for IR holding included as of $t-1 . C R I S I S_{i(t-5 \mid t-1)}$ is a vector of the numbers of crisis occurrences indicating how many times each of the three types of crises, i.e., currency, banking, and debt crises, occurred in the five pre-crisis years (i.e., from $t-5$ through $t-1$ ). We are interested in the coefficient $\phi$ to examine whether the frequency of crises in the (relatively immediate) past would affect the degree of relative policy divergence $(d)$. If our hypothesis is held, the estimated coefficient $\hat{\phi}$ should be significantly negative, suggesting that countries with frequent crisis experiences tend to reduce the degree of trilemma policy divergence.

Table 4 reports the estimation results for the full sample and the subsamples of industrialized, developing and emerging market countries. It turns out that the estimated

\footnotetext{
${ }^{27}$ The dummy for ERM countries is assigned for the countries and years that corresponds to participation in the ERM (i.e., Belgium, Germany, France, Ireland, Italy, and Luxembourg from 1979 on; Spain from 1989; U.K. only for 1990-91; Portugal from 1992; Austria from 1995; Finland from 1996; and Denmark and Greece from 1999) or ERM II (Estonia, Lithuania, and Slovenia from 2004; and Cyprus, Latvia, Malta, and Slovak Rep. from 2005).
} 
coefficient on the dummy for past currency crisis occurrences is persistently, significantly negative. The more times a country experiences a currency crisis in the past five years, the more likely it is to reduce the extent of triad policy convergence, which supports our hypothesis, though the correlation is not found for banking or debt crisis. ${ }^{28}$

We take a closer look at the impact of past crisis experiences on the extent of triad relative policy divergence by estimating the autoregressive effect of past crisis experiences as it follows:

$$
\begin{aligned}
d_{i t}=\gamma_{0}+\gamma_{1} d_{i t-1} & +Z_{i t}{ }^{\prime} \Gamma \\
& +\sum_{i=n}^{10} \beta_{C, t-n} \cdot\left(\omega_{t-n} \cdot \operatorname{CRISIS}_{i, t-n}\right)+\sum_{i=n}^{10} \beta_{T C, t-n} \cdot\left(\omega_{t-n} \cdot \operatorname{TWCRISIS}_{i, t-n}\right)+v_{i t} .
\end{aligned}
$$

CRISIS $_{i, t-n}$ is a vector of the dummies for the onsets of the three different types of crises from $t-1$ through $t-10$. We also assume that policy makers would put more weight on recent crisis episodes when making policy decisions. $\omega_{t-n}$ indicates the weight policy makers would place on the crisis episode in year $t-n$ while we assume that the weight diminishes by $5 \%$ every year, i.e., that the memory of a crisis among policy makers "depreciates" at the annual rate of $5 \%{ }^{29}$ TWCRISIS $_{i, t-n}$ is a comparable vector of the dummies for the three types of twin crises: TWCRISIS $^{C B}$ (currency and banking crisis), TWCRISIS ${ }^{C D}$ (currency and debt), and TWCRISIS ${ }^{B D}$ (banking and debt). We run the estimation model of equation (4) first without TWCRISIS and then with TWCRISIS. We focus on the autoregressive estimates, $\beta_{C}$ and $\beta_{T C}$.

\footnotetext{
${ }^{28}$ When we extend the model by including the number of crisis occurrences in the times $t-10$ through $t-6$, in addition to those for the times $t-5$ through $t-1$, the results are still found to be robust while none of those crisis occurrences from $t-10$ through $t-6$ turned out to be significant contributors (not reported).

${ }^{29}$ Hence, $\omega_{t-n}$ takes the value of one for the immediate previous year (i.e., $t-1$ ), then $\omega_{t-2}=0.95$ for $t-2$, $\omega_{t-2}=0.90$ for $t-3$, and so forth.
} 
The upper half of Table 5 reports only significant autoregressive estimates (with the regressive weights) for the crisis dummies, i.e., $\hat{\beta}_{c}$. It must be noted that the estimation model does not include the twin crisis dummies.

From the table, we can confirm that the degree of triad relative policy divergence can be affected by past crisis experiences. Developing countries on average tend to reduce the extent of relative policy divergence two years after experiencing (the onset of) a currency crisis. Considering that the average duration of a currency crisis for developing countries is about 2 years, we can infer that countries tend to reduce $d$ once the currency crisis ends. Emerging market countries tend to reduce $d$ five years after experiencing a banking crisis, that is two years after the average duration of a banking crisis of three years. They also tend to reduce $d$ eight years after experiencing a debt crisis, that is three and a half years after the average duration of a banking crisis of 4.5 years.

What about the impact of twin crisis? The bottom half of Table 5 displays estimates only the estimated coefficients of the (weighted) autoregressive dummies for twin crises that are included in the estimation model along with the (weighted) autoregressive singular crisis variables though the estimates for the latter are not reported. Given the inclusion of the autoregressive singular crisis dummies, the estimates on the twin crisis dummies should be regarded as representing the marginal effect of past twin crises.

From the table, we can see that if a developing country experiences a currency-banking twin crisis, it tends to reduce its degree of relative policy divergence three years later (while the average duration of the currency-banking crisis is about three years). If it experiences a currencydebt twin crisis, the country tends to lower its degree of relative policy divergence four years 
after the crisis occurrence, but raise it again in the seventh year. ${ }^{30}$ If it experiences a bankingdebt twin crisis, the country tends to raise its degree of relative policy divergence nine years after the crisis occurrence.

As we have discussed several times, an occurrence of a crisis does not necessarily mean that the crisis would involve output losses. Policy makers may end up taking no action if the crisis does not leave any damage or output losses to their economy.

Hence, we modify the estimation model as follows. Instead of looking at the (regressive) impacts of past crises, we examine the impacts only for the crises that accompany output losses. Now, the estimation equation becomes:

$$
\begin{aligned}
d_{i t}=\gamma_{0}+\gamma_{1} d_{i t-1}+Z_{i t}{ }^{\prime} & \Gamma+\sum_{i=n}^{10} \beta_{C O L, t-n} \cdot \omega_{t-n}\left(\text { CRISIS }_{i, t-n} \cdot O L_{i, t-n}\right) \\
& +\sum_{i=n}^{10} \beta_{T W O L, t-n} \cdot \omega_{t-n}\left(\text { TWCRISIS }_{i, t-n} \cdot \text { TWOL }_{i, t-n}\right)+\eta_{i t} .
\end{aligned}
$$

The CRISIS $_{i, t-n}$ dummy is interacted with the dummy for positive output losses $\left(O L_{i, t-n}\right)$. That is, if the accumulated output losses are positive, we assign the value of one for $O L$. In tranquil years or crisis times with no ex post output losses, the term $\left(C R I S I S_{i, t-n} \cdot O L_{i, t-n}\right)$ takes the value of zero. The term $\left(\right.$ TWCRISIS $_{i, t-n} \cdot$ TWOL $\left._{i, t-n}\right)$ can be interpreted similarly with $T W O L_{i, t-n}$ denoting the dummy for positive output losses that accompany a twin crisis.

Again, the upper half of Table 6 reports the impact of an onset of a crisis accompanying output losses in ex post on the degree of triad relative policy divergence when we estimate equation (5) without the dummies for twin crises accompanying output losses. The lower half of the table reports the 'marginal' impacts of twin crises with output losses.

Developing countries would raise its degree of relative policy divergence in the year immediately after an onset of a currency crisis that would lead to output losses, but it is followed

\footnotetext{
${ }^{30}$ The average duration of a currency-debt crisis is 3.16 for LDCs and 3.77 for EMGs.
} 
by reductions in $d$ in the second and fifth years. The immediate rise in $d$ may reflect stabilization efforts taken by the currency crisis country as we have discussed previously. Compared to the previous case with just the dummies for crises, the absolute magnitude of the estimated coefficients on the currency crisis from $t-2$ is larger and $d$ gets reduced twice instead of just once, indicating that countries may reduce the level of $d$ when they experience a currency crisis and output losses.

The results for the marginal effects of twin crises with output losses are reported in the bottom half of Table 6 and cast interesting contrasts with the comparable part of Table 5 . Developing countries would respond to an onset of a currency-banking crisis faster (in the second and third years instead of just the third year) when a crisis takes place in a way that involves output losses. Emerging market countries would reduce the $d$ more significantly when they experience a currency-banking crisis with output losses. The negative response to a currency-debt crisis is greater when they experience output losses as well. Overall, the currencybanking crisis seems to lead to a largest fall in $d$ among developing and emerging market countries if it ends up entailing output losses, and the size of fall is larger for the group of emerging market countries.

\section{Conclusion}

We have examined the impact of open macro policies on economic performance from the perspective of the powerful Trilemma hypothesis - a country may not simultaneously attain monetary independence, exchange rate stability, and financial openness. In this paper, we shed light on the impact of relative trilemma policy divergence by measuring how far a country's 
trilemma policy combination differs from the world trend and evaluating its impact on economic stability.

When we compared the degree of relative policy divergence across countries among different income levels and also geographical groups, we focused on the trend in the last two decades that emerging market countries have adopted trilemma policy combinations with the smallest degree of policy divergence. Given that emerging market countries has achieved a relatively stable output performance, lower levels of relative policy divergence may have been one of the key reasons for to it.

To investigate that, we formally tested the effect of the degree of relative policy divergence on the probability of crisis occurrences and on crisis-driven output losses. We have found that a developing or emerging market country with a higher degree of relative policy divergence is more likely to experience currency or debt crises.

When we investigated the impact of relative policy divergence on the output losses that arise from a crisis, we found that a developing or emerging market country with a higher degree of relative policy divergence tends to experience smaller output losses once it experiences a currency or banking crisis.

These two sets of empirical results may appear contradictory to each other, especially for the case of a currency crisis. However, we think that having a larger degree of relative policy divergence in the years before the onset of a crisis can be a result of stabilization measures. If such efforts are made without changing the other two policies, it would increase the pressure for market corrections, thereby increasing the probability of a crisis. Once a crisis occurs, the larger the pre-crisis policy efforts are, the more pressure would be defused, so that its output cost would 
be smaller. Among the trilemma policies, stabilization efforts through greater monetary independence are found to be essential.

Lastly, we also investigated the endogenous nature of the degree of policy divergence. Countries may respond to crisis experiences by changing the degree of relative policy divergence. Naturally, we may presume that the more frequently a country experienced crises, the lower the degree of relative policy divergence it would want to pursue. We found empirical evidence that the number of crisis experiences does tend to reduce the degree of policy divergence. Developing countries tend to reduce the degree of relative policy divergence especially when they experienced a currency crisis or a currency-banking crisis, and that tendency can be even stronger when the crisis accompanies output losses.

Acknowledgements: We gratefully acknowledge the financial support of faculty research funds of USC and PSU. We also thank Jacinta Bernadette Rico for excellent research assistance, and Yong Wang and participants at the conference "Pacific Rim Economies and the Evolution of the International Monetary Architecture" held at City University of Hong Kong (CUHK) on December 19-20, 2013 and organized by CUHK and JIMF. 


\section{References}

Aizenman, J., and H. Ito. 2013. "Living with the Trilemma Constraint: Relative Trilemma Policy Divergence, Crises, and Output Losses for Developing,” NBER Working Paper \#19448, Cambridge: National Bureau of Economic Research.

Aizenman, J., and H. Ito. 2012. "Trilemma Policy Convergence Patterns and Output Volatility." North American Journal of Economics and Finance, Volume 23, Issue 3, December 2012, Pages 269-285 (December 2012).

Aizenman, J., M.D. Chinn, and H. Ito. 2013. “The 'Impossible Trinity' Hypothesis in an Era of Global Imbalances: Measurement and Testing.” Review of International Economics, 21(3), 447-458.

Aizenman, J., M.D. Chinn, and H. Ito. 2011. "Surfing the Waves of Globalization: Asia and Financial Globalization in the Context of the Trilemma," Journal of the Japanese and International Economies, vol. 25(3), p. 290 - 320 (September).

Aizenman, J., M. D. Chinn and H. Ito. 2010. The Emerging Global Financial Architecture: Tracing and Evaluating the New Patterns of the Trilemma's Configurations, Journal of International Money and Finance, Vol. 29, No. 4, p. 615-641.

Borio, C. E. V. and P. Disyatat. 2011.”Global Imbalances and the Financial Crisis: Link or No Link?” BIS Working Paper No. 346 (May 1).

Bruno, V. and H. S. Shin. 2012. "Capital Flows, Cross-Border Banking and Global Liquidity,” Princeton Working Paper.

Chinn, M. D. and H. Ito. 2008. A New Measure of Financial Openness. Journal of Comparative Policy Analysis, Volume 10, Issue 3 (September), p. 309 - 322. 
Chinn, M. D. and H. Ito, 2006. What Matters for Financial Development? Capital Controls, Institutions, and Interactions, Journal of Development Economics, Volume 81, Issue 1, Pages 163-192.

Demirgüç-Kunt, A., Detragiache, E., 1998. The determinants of banking crises in developing and developed countries. IMF Staff Papers 45, 81-109.

Duttagupta, R. and P. Cashin. 2011. Anatomy of banking Crises in Developing and Emerging Market Countries, Journal of International Money and Finance, 30(2), p. 354-376.

Demirgüç-Kunt, A., B. Karacaovali and L. Laeven. 2005. "Deposit Insurance around the World: A Comprehensive Database.” World Bank Policy Research Working Paper no. 3628.Washington, DC: World Bank.

Glick, R. and M. Hutchison. 2001. "Banking and Currency Crises: How Common Are Twins?" In R. Glick, R. Moreno, and M. Spiegel, eds. Financial Crises in Emerging Markets. Cambridge, UK: Cambridge University Press, Chapter 2.

Hutchison, M. 2003. "A Cure Worse than the Disease? Currency Crises and the Output Costs of IMF-supported Stabilization Programs," In M. Dooley and J. A. Frankel, eds. Managing Currency Crises in Emerging Markets, Chicago: University of Chicago Press.

Joyce, J. 2012. The IMF and Global Financial Crises, Cambridge University Press.

Joyce, J. 2011. "Financial Globalization and Banking Crises in Emerging Markets," Open Economies Review, vol. 22 no. 5 .

Kaminsky, G. 2003. "Varieties of Currency Crises" NBER Working Paper Series, \#10193.

Kaminsky, G.L. and C. M. Reinhart. 1999. "The Twin Crises: The Causes of Banking and Balance-of-Payments Problems," American Economic Review, vol. 89(3), pages 473-500. 
Kaminsky, G., S. Lizondo, and C. Reinhart. 1998. "Leading Indicators of Currency Crises," International Monetary Fund Staff Papers, 45, March, 1-48.

Kaminsky, G. and S. Schmukler. 2002, "Short-Run Pain, Long-Run Gain: The Effects of Financial Liberalization,” World Bank Working Paper No. 2912.

Laeven, L. and F. Valencia. 2008. "Systematic Banking Crises: A New Database,” IMF Working Paper WP/08/224, Washington, D.C.: International Monetary Fund.

Laeven, L. and F. Valencia. 2010. "Resolution of Banking Crises: The Good, the Bad, and the Ugly,” IMF Working Paper No. 10/44. Washington, D.C.: International Monetary Fund. Laeven, L. and F. Valencia. 2012. "Systematic Banking Crises: A New Database," IMF Working Paper WP/12/163, Washington, D.C.: International Monetary Fund.

Lane, P., and G. M. Milesi-Ferretti. 2007. The External Wealth of Nations Mark II: Revised and Extended Estimates of Foreign Assets and Liabilities, 1970-2004. Journal of International Economics 73(2): 223-250.

Obstfeld, M.. 2012a. "Financial Flows, Financial Crises, and Global Imbalances, Journal of International Money and Finance, 31, p. 469-480.

Obstfeld, M. 2012b. "Does the Current Account Still Matter?", American Economic Review, 102(3), 1-23.

Przeworski, A. and J. R. Vreeland. 2000. "The Effect of IMF Programs on Economic Growth," Journal of Development Economics, Vol. 62. 385-421.

von Hagen J. and T.K. Ho. 2007. "Money Market Pressure and the Determinants of Banking Crises," Journal of Money, Credit and Banking, vol. 39(5), pages 1037-1066, 08. 
Table 1: Probit Estimations on the Probabilities of Different Types of Crisis Occurrences

\begin{tabular}{|c|c|c|c|c|c|c|c|c|c|c|}
\hline & $\begin{array}{l}\text { (1) Currency } \\
\text { Full } \\
\end{array}$ & $\begin{array}{l}\text { (2) Currency } \\
\text { IDC }\end{array}$ & $\begin{array}{l}\text { (3) Currency } \\
\text { LDC }\end{array}$ & $\begin{array}{c}\text { (4) Currency } \\
\text { EMG }\end{array}$ & $\begin{array}{l}\text { (5) Banking } \\
\text { FULL }\end{array}$ & $\begin{array}{l}\text { (6) Banking } \\
\text { IDC }\end{array}$ & $\begin{array}{l}\text { (7) Banking } \\
\text { LDC }\end{array}$ & $\begin{array}{l}\text { (8) Banking } \\
\text { EMG }\end{array}$ & $\begin{array}{l}\text { (9) Debt } \\
\text { LDC }\end{array}$ & $\begin{array}{c}\text { (10) Debt } \\
\text { EMG }\end{array}$ \\
\hline $\begin{array}{c}\text { Relative income } \\
(t-1)\end{array}$ & $\begin{array}{c}0.041 \\
(0.015)^{* * *}\end{array}$ & $\begin{array}{l}0.051 \\
(0.035)\end{array}$ & $\begin{array}{c}0.064 \\
(0.027)^{* *}\end{array}$ & $\begin{array}{l}0.026 \\
(0.040)\end{array}$ & $\begin{array}{l}-0.017 \\
(0.014)\end{array}$ & $\begin{array}{l}0.001 \\
(0.004)\end{array}$ & $\begin{array}{l}0.012 \\
(0.026)\end{array}$ & $\begin{array}{l}0.026 \\
(0.037)\end{array}$ & $\begin{array}{c}-0.108 \\
(0.049)^{* *}\end{array}$ & $\begin{array}{l}-0.023 \\
(0.026)\end{array}$ \\
\hline IR holding $(t-1)$ & $\begin{array}{l}-0.004 \\
(0.041)\end{array}$ & $\begin{array}{l}-0.156 \\
(0.135)\end{array}$ & $\begin{array}{l}0.001 \\
(0.044)\end{array}$ & $\begin{array}{l}0.008 \\
(0.075)\end{array}$ & $\begin{array}{c}-0.093 \\
(0.041)^{* *}\end{array}$ & $\begin{array}{l}0.003 \\
(0.016)\end{array}$ & $\begin{array}{c}-0.131 \\
(0.047)^{* * *}\end{array}$ & $\begin{array}{l}-0.122 \\
(0.064)^{*}\end{array}$ & $\begin{array}{c}-0.124 \\
(0.050)^{* *}\end{array}$ & $\begin{array}{c}-0.079 \\
(0.031)^{* *}\end{array}$ \\
\hline $\begin{array}{c}\text { Per Capita } \\
\text { Output growth }(t-1)\end{array}$ & $\begin{array}{l}-0.071 \\
(0.078)\end{array}$ & $\begin{array}{l}-0.243 \\
(0.206)\end{array}$ & $\begin{array}{l}-0.032 \\
(0.077)\end{array}$ & $\begin{array}{l}0.016 \\
(0.161)\end{array}$ & $\begin{array}{l}-0.124 \\
(0.067)^{*}\end{array}$ & $\begin{array}{l}-0.063 \\
(0.053)\end{array}$ & $\begin{array}{l}-0.063 \\
(0.069)\end{array}$ & $\begin{array}{l}-0.032 \\
(0.115)\end{array}$ & $\begin{array}{l}-0.134 \\
(0.113)\end{array}$ & $\begin{array}{c}-0.214 \\
(0.088)^{* *}\end{array}$ \\
\hline $\begin{array}{c}\text { Private Credit change } \\
\qquad(t-1)\end{array}$ & $\begin{array}{c}0.015 \\
(0.067)\end{array}$ & $\begin{array}{c}0.056 \\
(0.079)\end{array}$ & $\begin{array}{l}0.035 \\
(0.088)\end{array}$ & $\begin{array}{c}0.190 \\
(0.096)^{* *}\end{array}$ & $\begin{array}{c}0.097 \\
(0.045)^{* *}\end{array}$ & $\begin{array}{c}0.002 \\
(0.012)\end{array}$ & $\begin{array}{c}0.209 \\
(0.070)^{* * *}\end{array}$ & $\begin{array}{c}0.150 \\
(0.076)^{* *}\end{array}$ & $\begin{array}{l}-0.104 \\
(0.128)\end{array}$ & $\begin{array}{l}-0.070 \\
(0.065)\end{array}$ \\
\hline Net Debt $(t-1)$ & $\begin{array}{l}0.006 \\
(0.006)\end{array}$ & $\begin{array}{l}-0.004 \\
(0.015)\end{array}$ & $\begin{array}{c}0.021 \\
(0.007)^{* * *}\end{array}$ & $\begin{array}{c}0.052 \\
(0.023)^{* *}\end{array}$ & $\begin{array}{l}0.008 \\
(0.006)\end{array}$ & $\begin{array}{l}0.005 \\
(0.004)\end{array}$ & $\begin{array}{l}0.007 \\
(0.008)\end{array}$ & $\begin{array}{l}-0.002 \\
(0.016)\end{array}$ & $\begin{array}{c}0.046 \\
(0.015)^{* * *}\end{array}$ & $\begin{array}{l}0.006 \\
(0.012)\end{array}$ \\
\hline $\begin{array}{c}\text { Real Exchange } \\
\text { Overvaluation }(t-1)\end{array}$ & $\begin{array}{c}0.019 \\
(0.010)^{*}\end{array}$ & $\begin{array}{c}0.105 \\
(0.041)^{* *}\end{array}$ & $\begin{array}{l}0.007 \\
(0.009)\end{array}$ & $\begin{array}{l}-0.004 \\
(0.020)\end{array}$ & $\begin{array}{l}0.005 \\
(0.013)\end{array}$ & $\begin{array}{l}0.010 \\
(0.008)\end{array}$ & $\begin{array}{l}0.003 \\
(0.015)\end{array}$ & $\begin{array}{c}0.011 \\
(0.020)\end{array}$ & $\begin{array}{l}-0.002 \\
(0.014)\end{array}$ & $\begin{array}{l}-0.001 \\
(0.011)\end{array}$ \\
\hline $\begin{array}{c}\text { Financial Exposure } \\
(t-1)\end{array}$ & $\begin{array}{c}-0.017 \\
(0.006)^{* * *}\end{array}$ & $\begin{array}{l}-0.023 \\
(0.011)^{* *}\end{array}$ & $\begin{array}{l}-0.002 \\
(0.009)\end{array}$ & $\begin{array}{l}-0.025 \\
(0.019)\end{array}$ & $\begin{array}{c}0.013 \\
(0.004)^{* * *}\end{array}$ & $\begin{array}{l}0.004 \\
(0.004)\end{array}$ & $\begin{array}{c}0.015 \\
(0.006)^{* * *}\end{array}$ & $\begin{array}{c}0.010 \\
(0.007)\end{array}$ & $\begin{array}{l}-0.007 \\
(0.016)\end{array}$ & $\begin{array}{l}-0.012 \\
(0.014)\end{array}$ \\
\hline $\operatorname{ERS}(t-1)$ & $\begin{array}{l}-0.012 \\
(0.011)\end{array}$ & $\begin{array}{l}-0.025 \\
(0.019)\end{array}$ & $\begin{array}{l}0.006 \\
(0.012)\end{array}$ & $\begin{array}{l}0.001 \\
(0.018)\end{array}$ & $\begin{array}{c}0.009 \\
(0.009)\end{array}$ & $\begin{array}{l}-0.002 \\
(0.004)\end{array}$ & $\begin{array}{c}0.009 \\
(0.011)\end{array}$ & $\begin{array}{l}0.020 \\
(0.017)\end{array}$ & $\begin{array}{c}0.035 \\
(0.016)^{* *}\end{array}$ & $\begin{array}{l}0.016 \\
(0.012)\end{array}$ \\
\hline $\operatorname{KAOPEN}(t-1)$ & $\begin{array}{c}-0.042 \\
(0.015)^{* * *}\end{array}$ & $\begin{array}{l}-0.027 \\
(0.024)\end{array}$ & $\begin{array}{l}-0.024 \\
(0.015)\end{array}$ & $\begin{array}{l}-0.023 \\
(0.021)\end{array}$ & $\begin{array}{l}-0.009 \\
(0.012)\end{array}$ & $\begin{array}{l}-0.003 \\
(0.007)\end{array}$ & $\begin{array}{l}-0.011 \\
(0.013)\end{array}$ & $\begin{array}{l}-0.015 \\
(0.018)\end{array}$ & $\begin{array}{l}-0.001 \\
(0.016)\end{array}$ & $\begin{array}{l}-0.016 \\
(0.011)\end{array}$ \\
\hline Tri. Pol. Conv $(t-1)$ & $\begin{array}{c}0.001 \\
(0.011)\end{array}$ & $\begin{array}{l}-0.022 \\
(0.014)\end{array}$ & $\begin{array}{c}0.036 \\
(0.014)^{* * * *}\end{array}$ & $\begin{array}{c}0.043 \\
(0.019)^{* *}\end{array}$ & $\begin{array}{l}0.005 \\
(0.010)\end{array}$ & $\begin{array}{c}0.002 \\
(0.003)\end{array}$ & $\begin{array}{l}-0.000 \\
(0.013)\end{array}$ & $\begin{array}{c}0.011 \\
(0.017)\end{array}$ & $\begin{array}{c}0.051 \\
(0.017)^{* * *}\end{array}$ & $\begin{array}{c}0.024 \\
(0.010)^{* *}\end{array}$ \\
\hline $\begin{array}{l}\text { Tri-Pol. Conv., SD } \\
\qquad(t-5 \mid t-1)\end{array}$ & $\begin{array}{l}0.035 \\
(0.036)\end{array}$ & $\begin{array}{l}-0.001 \\
(0.053)\end{array}$ & $\begin{array}{c}0.039 \\
(0.041)\end{array}$ & $\begin{array}{c}0.052 \\
(0.057)\end{array}$ & $\begin{array}{l}0.045 \\
(0.033)\end{array}$ & $\begin{array}{l}0.012 \\
(0.012)\end{array}$ & $\begin{array}{l}0.027 \\
(0.042)\end{array}$ & $\begin{array}{l}0.024 \\
(0.056)\end{array}$ & $\begin{array}{c}0.081 \\
(0.053)^{13 \%}\end{array}$ & $\begin{array}{c}0.038 \\
(0.025)^{11 \%}\end{array}$ \\
\hline $\begin{array}{c}\text { Contagion: Currency } \\
(t \text { or } t-l)\end{array}$ & $\begin{array}{c}0.143 \\
(0.030)^{* * *}\end{array}$ & $\begin{array}{c}0.078 \\
(0.047)^{*}\end{array}$ & $\begin{array}{c}0.135 \\
(0.031)^{* * *}\end{array}$ & $\begin{array}{c}0.117 \\
(0.066)^{*}\end{array}$ & $\begin{array}{l}-0.050 \\
(0.035)\end{array}$ & $\begin{array}{l}-0.024 \\
(0.021)\end{array}$ & $\begin{array}{l}-0.042 \\
(0.036)\end{array}$ & $\begin{array}{c}0.025 \\
(0.049)\end{array}$ & $\begin{array}{c}0.076 \\
(0.040)^{*}\end{array}$ & $\begin{array}{l}-0.019 \\
(0.045)\end{array}$ \\
\hline $\begin{array}{c}\text { Contagion: Banking } \\
\quad(t \text { or } t-1)\end{array}$ & $\begin{array}{l}0.035 \\
(0.025)\end{array}$ & $\begin{array}{l}-0.034 \\
(0.036)\end{array}$ & $\begin{array}{c}0.055 \\
(0.024)^{* *}\end{array}$ & $\begin{array}{c}0.093 \\
(0.034)^{* * *}\end{array}$ & $\begin{array}{c}0.124 \\
(0.018)^{* * *}\end{array}$ & $\begin{array}{l}0.027 \\
(0.026)\end{array}$ & $\begin{array}{c}0.073 \\
(0.019)^{* * *}\end{array}$ & $\begin{array}{c}0.089 \\
(0.027)^{* * * *}\end{array}$ & $\begin{array}{l}-0.022 \\
(0.038)\end{array}$ & $\begin{array}{l}0.007 \\
(0.025)\end{array}$ \\
\hline $\begin{array}{l}\text { Contagion: Debt } \\
\quad(t \text { or } t-l)\end{array}$ & $\begin{array}{l}-0.015 \\
(0.032)\end{array}$ & $\begin{array}{l}-0.075 \\
(0.127)\end{array}$ & $\begin{array}{l}-0.003 \\
(0.034)\end{array}$ & $\begin{array}{c}0.046 \\
(0.061)\end{array}$ & $\begin{array}{l}0.005 \\
(0.043)\end{array}$ & $\begin{array}{l}0.046 \\
(0.044)\end{array}$ & $\begin{array}{l}-0.023 \\
(0.034)\end{array}$ & $\begin{array}{l}0.005 \\
(0.056)\end{array}$ & $\begin{array}{c}-0.234 \\
(0.053)^{* * *}\end{array}$ & $\begin{array}{c}-0.129 \\
(0.034)^{* * *}\end{array}$ \\
\hline $\begin{array}{l}\text { Banking Crisis } \\
\quad(\mathrm{t} \text { or } \mathrm{t}-1)\end{array}$ & $\begin{array}{c}0.102 \\
(0.029)^{* * *}\end{array}$ & & $\begin{array}{c}0.107 \\
(0.032)^{* * *}\end{array}$ & $\begin{array}{c}0.124 \\
(0.044)^{* * *}\end{array}$ & & & & & $\begin{array}{c}0.030 \\
(0.024)\end{array}$ & $\begin{array}{l}0.027 \\
(0.019)\end{array}$ \\
\hline $\begin{array}{l}\text { Debt Crisis } \\
(\mathrm{t} \text { or } \mathrm{t}-1)\end{array}$ & $\begin{array}{l}0.007 \\
(0.014)\end{array}$ & & $\begin{array}{l}0.001 \\
(0.012)\end{array}$ & $\begin{array}{l}0.009 \\
(0.024)\end{array}$ & $\begin{array}{l}-0.004 \\
(0.009)\end{array}$ & & $\begin{array}{l}-0.006 \\
(0.010)\end{array}$ & $\begin{array}{l}0.011 \\
(0.020)\end{array}$ & & \\
\hline $\begin{array}{l}\text { Currency Crisis } \\
(\mathrm{t} \text { or } \mathrm{t}-1)\end{array}$ & & & & & $\begin{array}{c}0.056 \\
(0.020)^{* * *}\end{array}$ & & $\begin{array}{c}0.092 \\
(0.028)^{* * *}\end{array}$ & $\begin{array}{c}0.091 \\
(0.033)^{* * *}\end{array}$ & $\begin{array}{l}0.030 \\
(0.023)\end{array}$ & $\begin{array}{l}0.019 \\
(0.016)\end{array}$ \\
\hline$N$ & 2,407 & 662 & 1,745 & 932 & 2,372 & 627 & 1,745 & 906 & 1,562 & 847 \\
\hline
\end{tabular}

percentages) with associated z-statistic (for hypothesis of no effect) in parentheses below. $* p<0.1 ; * * p<0.05$; *** $p<0.01$. Robust standard errors in brackets. 
Table 2: Output Cost of Different Types of Crises

\begin{tabular}{|c|c|c|c|c|c|c|c|c|}
\hline & $\begin{array}{c}\text { Currency } \\
\text { FULL } \\
\text { (1) }\end{array}$ & $\begin{array}{l}\text { Currency } \\
\text { LDC } \\
\text { (2) }\end{array}$ & $\begin{array}{c}\text { Currency } \\
\text { EMG } \\
\text { (3) }\end{array}$ & $\begin{array}{c}\text { Banking } \\
\text { FULL } \\
\text { (4) }\end{array}$ & $\begin{array}{c}\text { Banking } \\
\text { LDC } \\
\text { (5) }\end{array}$ & $\begin{array}{c}\text { Banking } \\
\text { EMG } \\
(6)\end{array}$ & $\begin{array}{c}\text { Debt } \\
\text { LDC } \\
\text { (7) }\end{array}$ & $\begin{array}{c}\text { Debt } \\
\text { EMG } \\
(8)\end{array}$ \\
\hline $\begin{array}{c}\text { Relative income } \\
\left(t_{0}-1\right)\end{array}$ & $\begin{array}{r}0.003 \\
(0.167)\end{array}$ & $\begin{array}{c}0.818 \\
(0.393)^{* *}\end{array}$ & $\begin{array}{c}1.371 \\
(0.609)^{* *}\end{array}$ & $\begin{array}{l}0.064 \\
(0.193)\end{array}$ & $\begin{array}{c}0.673 \\
(0.431)\end{array}$ & $\begin{array}{c}1.299 \\
(0.562)^{* *}\end{array}$ & $\begin{array}{c}1.931 \\
(0.435)^{* * * *}\end{array}$ & $\begin{array}{l}-0.173 \\
(1.151)\end{array}$ \\
\hline IR holding $\left(t_{0}-1\right)$ & $\begin{array}{l}-0.259 \\
(0.232)\end{array}$ & $\begin{array}{l}-0.388 \\
(0.334)\end{array}$ & $\begin{array}{l}-0.453 \\
(0.576)\end{array}$ & $\begin{array}{l}-0.584 \\
(0.576)\end{array}$ & $\begin{array}{l}-0.690 \\
(0.793)\end{array}$ & $\begin{array}{l}0.579 \\
(0.999)\end{array}$ & $\begin{array}{l}-0.477 \\
(0.679)\end{array}$ & $\begin{array}{l}-1.837 \\
(1.080)\end{array}$ \\
\hline $\begin{array}{l}\text { Per capita GDP } \\
\text { Growth }\left(t_{0}-1\right)\end{array}$ & $\begin{array}{c}-3.340 \\
(1.123)^{* * *}\end{array}$ & $\begin{array}{c}-3.521 \\
(1.022)^{* * *}\end{array}$ & $\begin{array}{l}-0.456 \\
(1.445)\end{array}$ & $\begin{array}{c}-5.717 \\
(1.211)^{* * *}\end{array}$ & $\begin{array}{c}-6.004 \\
(1.313)^{* * *}\end{array}$ & $\begin{array}{l}-3.637 \\
(2.174)\end{array}$ & $\begin{array}{c}-2.779 \\
(0.854)^{* * * *}\end{array}$ & $\begin{array}{l}-4.159 \\
(1.887)^{* *}\end{array}$ \\
\hline $\begin{array}{l}\text { Private Credit change } \\
\qquad\left(t_{0}-1\right)\end{array}$ & $\begin{array}{l}1.007 \\
(0.753)\end{array}$ & $\begin{array}{l}1.503 \\
(0.907)\end{array}$ & $\begin{array}{r}0.756 \\
(1.641)\end{array}$ & $\begin{array}{c}0.688 \\
(1.026)\end{array}$ & $\begin{array}{c}0.701 \\
(2.521)\end{array}$ & $\begin{array}{c}4.961 \\
(2.801)^{*}\end{array}$ & $\begin{array}{l}-0.612 \\
(0.994)\end{array}$ & $\begin{array}{l}-2.246 \\
(1.278)^{*}\end{array}$ \\
\hline Exch. Overval.( $\left.\mathrm{t}_{0}-1\right)$ & $\begin{array}{c}0.702 \\
(0.154)^{* * *}\end{array}$ & $\begin{array}{c}0.729 \\
(0.195)^{* * *}\end{array}$ & $\begin{array}{c}0.518 \\
(0.262)^{*}\end{array}$ & $\begin{array}{l}-0.057 \\
(0.098)\end{array}$ & $\begin{array}{l}-0.060 \\
(0.126)\end{array}$ & $\begin{array}{r}0.286 \\
(0.246)\end{array}$ & $\begin{array}{c}0.231 \\
(0.104)^{* *}\end{array}$ & $\begin{array}{l}0.215 \\
(0.246)\end{array}$ \\
\hline Net $\operatorname{Debt}\left(\mathrm{t}_{0^{-}}-1\right)$ & $\begin{array}{l}-0.025 \\
(0.158)\end{array}$ & $\begin{array}{l}0.151 \\
(0.193)\end{array}$ & $\begin{array}{c}1.071 \\
(0.403) * *\end{array}$ & $\begin{array}{l}-0.059 \\
(0.101)\end{array}$ & $\begin{array}{l}-0.213 \\
(0.208)\end{array}$ & $\begin{array}{c}0.564 \\
(0.300)^{*}\end{array}$ & $\begin{array}{c}0.204 \\
(0.144)\end{array}$ & $\begin{array}{l}0.313 \\
(0.435)\end{array}$ \\
\hline $\begin{array}{c}\text { Financial exposure } \\
\left(t_{0}-1\right)\end{array}$ & $\begin{array}{r}0.057 \\
(0.157)\end{array}$ & $\begin{array}{r}0.049 \\
(0.161)\end{array}$ & $\begin{array}{c}0.266 \\
(0.367)\end{array}$ & $\begin{array}{c}0.074 \\
(0.033) * *\end{array}$ & $\begin{array}{l}0.322 \\
(0.276)\end{array}$ & $\begin{array}{c}0.778 \\
(0.595)\end{array}$ & $\begin{array}{l}-0.083 \\
(0.141)\end{array}$ & $\begin{array}{l}-0.036 \\
(0.312)\end{array}$ \\
\hline $\begin{array}{c}\text { Deposit Insurance } \\
\left(t_{0}-1\right)\end{array}$ & $\begin{array}{l}-0.105 \\
(0.073)\end{array}$ & $\begin{array}{l}-0.116 \\
(0.093)\end{array}$ & $\begin{array}{l}-0.128 \\
(0.130)\end{array}$ & $\begin{array}{c}-0.282 \\
(0.102)^{* * *}\end{array}$ & $\begin{array}{c}-0.379 \\
(0.134)^{* * *}\end{array}$ & $\begin{array}{l}-0.269 \\
(0.231)\end{array}$ & $\begin{array}{l}-0.169 \\
(0.099)^{*}\end{array}$ & $\begin{array}{c}0.092 \\
(0.134)\end{array}$ \\
\hline $\operatorname{ERS}\left(\mathrm{t}_{0}-1\right)$ & $\begin{array}{l}-0.254 \\
(0.132)^{*}\end{array}$ & $\begin{array}{l}-0.244 \\
(0.173)\end{array}$ & $\begin{array}{l}-0.289 \\
(0.238)\end{array}$ & $\begin{array}{l}-0.126 \\
(0.159)\end{array}$ & $\begin{array}{l}-0.161 \\
(0.208)\end{array}$ & $\begin{array}{l}-0.613 \\
(0.353)\end{array}$ & $\begin{array}{l}-0.097 \\
(0.141)\end{array}$ & $\begin{array}{l}-0.002 \\
(0.325)\end{array}$ \\
\hline $\operatorname{KAOPEN}\left(t_{0^{-}}-1\right)$ & $\begin{array}{c}0.133 \\
(0.123)\end{array}$ & $\begin{array}{c}0.142 \\
(0.123)\end{array}$ & $\begin{array}{c}0.516 \\
(0.190)^{* *}\end{array}$ & $\begin{array}{l}0.214 \\
(0.151)\end{array}$ & $\begin{array}{l}0.217 \\
(0.197)\end{array}$ & $\begin{array}{l}0.324 \\
(0.351)\end{array}$ & $\begin{array}{l}0.080 \\
(0.205)\end{array}$ & $\begin{array}{c}0.332 \\
(0.273)\end{array}$ \\
\hline Tri.Pol.Conv, $d\left(t_{0}-1\right)$ & $\begin{array}{l}-0.199 \\
(0.100)^{*}\end{array}$ & $\begin{array}{l}-0.279 \\
(0.142)^{*}\end{array}$ & $\begin{array}{c}-0.553 \\
(0.198)^{* * *}\end{array}$ & $\begin{array}{l}-0.176 \\
(0.121)\end{array}$ & $\begin{array}{l}-0.281 \\
(0.195)\end{array}$ & $\begin{array}{l}-0.334 \\
(0.277)\end{array}$ & $\begin{array}{l}-0.049 \\
(0.128)\end{array}$ & $\begin{array}{c}0.118 \\
(0.296)\end{array}$ \\
\hline $\begin{array}{c}\text { Tri-Pol. Conv., SD } \\
(t-5 \mid t-1)\end{array}$ & $\begin{array}{l}0.160 \\
(0.339)\end{array}$ & $\begin{array}{c}0.097 \\
(0.402)\end{array}$ & $\begin{array}{l}0.445 \\
(0.613)\end{array}$ & $\begin{array}{l}-0.217 \\
(0.337)\end{array}$ & $\begin{array}{l}-0.773 \\
(0.605)\end{array}$ & $\begin{array}{l}-1.322 \\
(0.966)\end{array}$ & $\begin{array}{l}-0.138 \\
(0.446)\end{array}$ & $\begin{array}{l}-0.690 \\
(0.866)\end{array}$ \\
\hline $\begin{array}{l}\text { Banking Crisis } \\
\left(t_{0}-1, t_{0} \text {, or } t_{0}+1\right)\end{array}$ & $\begin{array}{c}0.215 \\
(0.090)^{* *}\end{array}$ & $\begin{array}{c}0.229 \\
(0.102)^{* *}\end{array}$ & $\begin{array}{l}0.022 \\
(0.147)\end{array}$ & & & & $\begin{array}{c}0.205 \\
(0.140)\end{array}$ & $\begin{array}{c}0.049 \\
(0.223)\end{array}$ \\
\hline $\begin{array}{c}\text { Debt Crisis } \\
\left(t_{0}-1, t_{0} \text {, or } t_{0}+1\right)\end{array}$ & $\begin{array}{c}0.118 \\
(0.126)\end{array}$ & $\begin{array}{l}0.023 \\
(0.131)\end{array}$ & $\begin{array}{l}0.172 \\
(0.154)\end{array}$ & $\begin{array}{c}0.099 \\
(0.130)\end{array}$ & $\begin{array}{l}0.083 \\
(0.159)\end{array}$ & $\begin{array}{l}0.265 \\
(0.178)\end{array}$ & & \\
\hline $\begin{array}{l}\text { Currency Crisis } \\
\left(t_{0}-1, t_{0} \text {, or } t_{0}+1\right)\end{array}$ & & & & $\begin{array}{c}0.252 \\
(0.100) * *\end{array}$ & $\begin{array}{c}0.252 \\
(0.121)^{* *}\end{array}$ & $\begin{array}{l}-0.184 \\
(0.190)\end{array}$ & $\begin{array}{l}0.116 \\
(0.132)\end{array}$ & $\begin{array}{c}0.170 \\
(0.240)\end{array}$ \\
\hline Adjusted R2 & 0.47 & 0.53 & 0.37 & 0.28 & 0.27 & 0.40 & 0.40 & 0.22 \\
\hline$N$ & 126 & 95 & 56 & 92 & 69 & 36 & 130 & 41 \\
\hline
\end{tabular}

Notes: Robust standard errors in brackets. The dummy for the debt crisis of 1982 and the Asian financial crisis of 1997-98, and the global

financial crisis of 2008-10 are also included, but not reported. The estimates for the constant term are also omitted. The terms of trade shocks variable is removed from the currency crisis output loss estimations since it is persistently statistically insignificant. 
Table 3: Impact of $\boldsymbol{d}$ on Output Gap during the Tranquil Times

\begin{tabular}{|c|c|c|c|c|c|c|}
\hline & $\begin{array}{l}\text { Output gap } \\
\text { FULL } \\
\text { (1) }\end{array}$ & $\begin{array}{l}\text { Output gap } \\
\text { LDC } \\
\text { (2) }\end{array}$ & $\begin{array}{c}\text { Output gap } \\
\text { EMG } \\
\text { (3) }\end{array}$ & $\begin{array}{l}\text { Output gap } \\
\text { FULL } \\
(4)\end{array}$ & $\begin{array}{l}\text { Output gap } \\
\text { LDC } \\
\text { (5) }\end{array}$ & $\begin{array}{c}\text { Output gap } \\
\text { EMG } \\
(6)\end{array}$ \\
\hline Output gap $(t-1)$ & $\begin{array}{c}0.626 \\
(0.039)^{* * *}\end{array}$ & $\begin{array}{c}0.612 \\
(0.042)^{* * *}\end{array}$ & $\begin{array}{c}0.661 \\
(0.041)^{* * *}\end{array}$ & $\begin{array}{c}0.626 \\
(0.039) * * *\end{array}$ & $\begin{array}{c}0.612 \\
(0.042) * * *\end{array}$ & $\begin{array}{c}0.661 \\
(0.041)^{* * *}\end{array}$ \\
\hline $\begin{array}{l}\text { Relative income } \\
\qquad(t-1)\end{array}$ & $\begin{array}{c}-0.817 \\
(0.242)^{* * *}\end{array}$ & $\begin{array}{l}-1.007 \\
(0.667)\end{array}$ & $\begin{array}{c}-1.788 \\
(0.683)^{* * *}\end{array}$ & $\begin{array}{c}-0.830 \\
(0.250)^{* * *}\end{array}$ & $\begin{array}{l}-1.057 \\
(0.668)\end{array}$ & $\begin{array}{c}-1.831 \\
(0.684)^{* * *}\end{array}$ \\
\hline Credit growth $(t-1)$ & $\begin{array}{c}4.470 \\
(1.141)^{* * *}\end{array}$ & $\begin{array}{c}6.330 \\
(2.018) * * *\end{array}$ & $\begin{array}{c}3.588 \\
(2.175)^{*}\end{array}$ & $\begin{array}{c}4.441 \\
(1.147) * * *\end{array}$ & $\begin{array}{c}6.244 \\
(2.012) * * *\end{array}$ & $\begin{array}{c}3.630 \\
(2.170)^{*}\end{array}$ \\
\hline Real Exchange & 0.160 & 0.242 & 0.322 & 0.163 & 0.252 & 0.392 \\
\hline Overvaluation $(t-1)$ & $(0.248)$ & $(0.258)$ & $(0.560)$ & $(0.247)$ & $(0.256)$ & $(0.558)$ \\
\hline Net Debt $(t-1)$ & $\begin{array}{c}-0.707 \\
(0.225)^{* * *}\end{array}$ & $\begin{array}{c}-0.836 \\
(0.275)^{* * *}\end{array}$ & $\begin{array}{c}-0.802 \\
(0.344)^{* *}\end{array}$ & $\begin{array}{c}-0.691 \\
(0.222)^{* * *}\end{array}$ & $\begin{array}{c}-0.829 \\
(0.275)^{* * *}\end{array}$ & $\begin{array}{c}-0.863 \\
(0.343)^{* *}\end{array}$ \\
\hline $\begin{array}{l}\text { Financial Exposure } \\
\qquad(t-1)\end{array}$ & $\begin{array}{c}0.015 \\
(0.067)\end{array}$ & $\begin{array}{c}0.004 \\
(0.073)\end{array}$ & $\begin{array}{c}0.323 \\
(0.185)^{*}\end{array}$ & $\begin{array}{c}0.021 \\
(0.068)\end{array}$ & $\begin{array}{c}0.009 \\
(0.074)\end{array}$ & $\begin{array}{c}0.314 \\
(0.187)^{*}\end{array}$ \\
\hline $\operatorname{ERS}(t-1)$ & $\begin{array}{c}0.094 \\
(0.233)\end{array}$ & $\begin{array}{c}0.005 \\
(0.277)\end{array}$ & $\begin{array}{l}-0.131 \\
(0.373)\end{array}$ & $\begin{array}{c}0.104 \\
(0.240)\end{array}$ & $\begin{array}{c}0.002 \\
(0.279)\end{array}$ & $\begin{array}{l}-0.211 \\
(0.390)\end{array}$ \\
\hline $\operatorname{KAOPEN}(t-1)$ & $\begin{array}{c}0.584 \\
(0.219) * * *\end{array}$ & $\begin{array}{c}0.579 \\
(0.250)^{* *}\end{array}$ & $\begin{array}{c}0.851 \\
(0.313)^{* * *}\end{array}$ & $\begin{array}{c}0.546 \\
(0.218)^{* *}\end{array}$ & $\begin{array}{c}0.537 \\
(0.252)^{* *}\end{array}$ & $\begin{array}{c}0.783 \\
(0.312)^{* *}\end{array}$ \\
\hline Tri. Pol. Conv. $(t-1)$ & $\begin{array}{c}-0.499 \\
(0.184) * * *\end{array}$ & $\begin{array}{c}-0.565 \\
(0.267)^{* *}\end{array}$ & $\begin{array}{c}-1.133 \\
(0.308)^{* * *}\end{array}$ & & & \\
\hline Tri-Pol. Conv., SD & $\begin{array}{l}-0.610 \\
(0.576)\end{array}$ & $\begin{array}{l}-0.596 \\
(0.766)\end{array}$ & $\begin{array}{c}0.711 \\
(1.036)\end{array}$ & $\begin{array}{l}-0.618 \\
(0.581)\end{array}$ & $\begin{array}{l}-0.516 \\
(0.794)\end{array}$ & $\begin{array}{c}0.742 \\
(1.085)\end{array}$ \\
\hline Abs. Dev.: MI $(t-1)$ & & & & $\begin{array}{l}-0.312 \\
(0.222)\end{array}$ & $\begin{array}{c}-0.468 \\
(0.295)^{11 \%}\end{array}$ & $\begin{array}{l}-0.571 \\
(0.406)\end{array}$ \\
\hline $\begin{array}{l}\text { Abs. Dev.: ERS } \\
\qquad(t-1)\end{array}$ & & & & $\begin{array}{c}-0.531 \\
(0.320)^{*}\end{array}$ & $\begin{array}{c}-0.619 \\
(0.389)^{11 \%}\end{array}$ & $\begin{array}{c}-1.085 \\
(0.443)^{* *}\end{array}$ \\
\hline $\begin{array}{c}\text { Abs. Dev.: KAOPEN } \\
(t-1)\end{array}$ & & & & $\begin{array}{c}-0.295 \\
(0.169)^{*}\end{array}$ & $\begin{array}{c}-0.342 \\
(0.237)^{15 \%}\end{array}$ & $\begin{array}{c}-0.851 \\
(0.281)^{* * *}\end{array}$ \\
\hline Constant & $\begin{array}{c}1.021 \\
(0.272)^{* * *}\end{array}$ & $\begin{array}{c}1.191 \\
(0.381)^{* * * *}\end{array}$ & $\begin{array}{c}1.623 \\
(0.466)^{* * *}\end{array}$ & $\begin{array}{c}1.091 \\
(0.310)^{* * *}\end{array}$ & $\begin{array}{c}1.324 \\
(0.416)^{* * *}\end{array}$ & $\begin{array}{c}1.855 \\
(0.483)^{* * * *}\end{array}$ \\
\hline Adjusted R2 & 0.39 & 0.37 & 0.47 & 0.39 & 0.37 & 0.47 \\
\hline$N$ & 2,520 & 1,928 & 773 & 2,520 & 1,928 & 773 \\
\hline
\end{tabular}

Notes: $* p<0.1 ; * * p<0.05$; *** $p<0.01$. The estimates are converted to show the effect of change in percentage on the dependent variable. 
Table 4: Determinants of the Degree of Trilemma Policy Divergence

\begin{tabular}{|c|c|c|c|c|}
\hline & $\begin{array}{c}\text { Full } \\
(1)\end{array}$ & $\begin{array}{l}\text { IDC } \\
(2)\end{array}$ & $\begin{array}{c}\text { LDC } \\
(3)\end{array}$ & $\begin{array}{c}\text { EMG } \\
(4)\end{array}$ \\
\hline \multirow[t]{2}{*}{$d(t-1)$} & 0.828 & 0.914 & 0.761 & 0.753 \\
\hline & $(0.012)^{* * *}$ & $(0.017)^{* * *}$ & $(0.016)^{* * *}$ & $(0.024)^{* * *}$ \\
\hline \multirow[t]{2}{*}{ Relative income } & 0.028 & 0.043 & 0.003 & 0.034 \\
\hline & $(0.014)^{* *}$ & $(0.059)$ & $(0.027)$ & $(0.048)$ \\
\hline IR hodling & -0.072 & 0.046 & -0.034 & -0.100 \\
\hline (\% of GDP) & $(0.036)^{* *}$ & $(0.156)$ & $(0.041)$ & $(0.083)$ \\
\hline Trade openness & 0.023 & -0.001 & 0.029 & 0.048 \\
\hline$(\%$ of GDP) & $(0.010)^{* *}$ & $(0.028)$ & $(0.011) * * *$ & $(0.022)^{* *}$ \\
\hline \multirow[t]{2}{*}{ Share of the economy } & 0.637 & 0.099 & 0.339 & 0.651 \\
\hline & $(0.195)^{* * *}$ & $(0.237)$ & $(0.614)$ & $(0.714)$ \\
\hline \multirow[t]{2}{*}{ Manufacturer } & -0.011 & 0.012 & -0.024 & -0.059 \\
\hline & $(0.008)$ & $(0.025)$ & $(0.009) * * *$ & $(0.016)^{* * *}$ \\
\hline \multirow[t]{2}{*}{ EMU } & 0.030 & 0.018 & 0.037 & 0.054 \\
\hline & $(0.012)^{* *}$ & $(0.015)$ & $(0.032)$ & $(0.041)$ \\
\hline \multirow{2}{*}{$\begin{array}{l}\text { Currency crisis in } \\
\qquad(t-5 \mid t-1)\end{array}$} & -0.015 & -0.001 & -0.014 & -0.022 \\
\hline & $(0.005)^{* * *}$ & $(0.010)$ & $(0.005) * * *$ & $(0.008)^{* * *}$ \\
\hline Banking crisis in & 0.001 & -0.000 & 0.002 & -0.000 \\
\hline$(t-5 \mid t-1)$ & $(0.004)$ & $(0.008)$ & $(0.004)$ & $(0.007)$ \\
\hline Debt crisis in & 0.000 & & 0.001 & 0.000 \\
\hline$(t-5 \mid t-1)$ & $(0.003)$ & & $(0.003)$ & $(0.004)$ \\
\hline$R^{2}$ & 0.75 & 0.87 & 0.62 & 0.63 \\
\hline$N$ & 2,703 & 701 & 2,002 & 1,000 \\
\hline
\end{tabular}

NOTES: Robust standard errors in brackets * significant at 10\%; ** significant at 5\%; *** significant at $1 \%$. The dummy for ERM countries is assigned for the countries and years that corresponds to participation in the ERM (i.e., Belgium, Germany, France, Ireland, Italy, and Luxembourg from 1979 on; Spain from 1989; U.K. only for 1990-91; Portugal from 1992; Austria from 1995; Finland from 1996; and Denmark and Greece from 1999) or ERM II (Estonia, Lithuania, and Slovenia from 2004; and Cyprus, Latvia, Malta, and Slovak Rep. from 2005). 
Table 5: Effects of Past Crises on the Degree of Trilemma Policy Divergence

\begin{tabular}{|c|c|c|c|c|c|c|c|c|c|c|}
\hline \multicolumn{11}{|l|}{ Singular effect of Crisis } \\
\hline Full & $t-1$ & $t-2$ & $t-3$ & $t-4$ & $t-5$ & $t-6$ & $t-7$ & $t-8$ & $t-9$ & $t-10$ \\
\hline Currency & & -0.065 & & & -0.038 & & & & & \\
\hline \multicolumn{11}{|l|}{ Banking } \\
\hline \multicolumn{11}{|l|}{ Debt } \\
\hline Industrialized countries & $t-1$ & $t-2$ & $t-3$ & $t-4$ & $t-5$ & $t-6$ & $t-7$ & $t-8$ & $t-9$ & $t-10$ \\
\hline Currency & & & & & & & 0.075 & & & \\
\hline Banking & & & & & & & & -0.169 & & \\
\hline Debt & -- & -- & -- & -- & -- & -- & -- & -- & -- & -- \\
\hline Developing countries & $t-1$ & $t-2$ & $t-3$ & $t-4$ & $t-5$ & $t-6$ & $t-7$ & $t-8$ & $t-9$ & $t-10$ \\
\hline Currency & & -0.066 & & & & & & & & \\
\hline \multicolumn{11}{|l|}{ Banking } \\
\hline \multicolumn{11}{|l|}{ Debt } \\
\hline Emerging markets & $t-1$ & $t-2$ & $t-3$ & $t-4$ & $t-5$ & $t-6$ & $t-7$ & $t-8$ & $t-9$ & $t-10$ \\
\hline Currency & & -0.071 & & & & & & & & \\
\hline Banking & & & & & -0.082 & & & & & \\
\hline Debt & & & & & & & & -0.084 & & \\
\hline \multicolumn{11}{|c|}{ Twin Crises ('Marginal' Effects) } \\
\hline Full & $t-1$ & $t-2$ & $t-3$ & $t-4$ & $t-5$ & $t-6$ & $t-7$ & $t-8$ & $t-9$ & $t-10$ \\
\hline Currency \& Banking & & -0.081 & & & & & & & & \\
\hline Currency \& Debt & & & & -0.060 & & & & & & \\
\hline Banking \& Debt & & & & & & & & & 0.093 & \\
\hline Industrialized countries & $t-1$ & $t-2$ & $t-3$ & $t-4$ & $t-5$ & $t-6$ & $t-7$ & $t-8$ & $t-9$ & $t-10$ \\
\hline Currency \& Banking & & & & 0.384 & & & & & & \\
\hline-- & -- & -- & -- & -- & -- & -- & -- & -- & -- & -- \\
\hline-- & -- & -- & -- & -- & -- & -- & -- & -- & -- & -- \\
\hline Developing countries & $t-1$ & $t-2$ & $t-3$ & $t-4$ & $t-5$ & $t-6$ & $t-7$ & $t-8$ & $t-9$ & $t-10$ \\
\hline Currency \& Banking & & & -0.110 & & & & & & & \\
\hline Currency \& Debt & & & & -0.066 & & & 0.103 & & & \\
\hline Banking \& Debt & & & & & & & & & 0.097 & \\
\hline Emerging markets & $t-1$ & $t-2$ & $t-3$ & $t-4$ & $t-5$ & $t-6$ & $t-7$ & $t-8$ & $t-9$ & $t-10$ \\
\hline Currency \& Banking & & & -0.137 & & & & & & & \\
\hline Currency \& Debt & & & & -0.106 & & & & & & \\
\hline Banking \& Debt & & 0.135 & & 0.193 & & & & & & \\
\hline
\end{tabular}

Notes: The upper half of the table reports only the significant weighted autoregressive estimates for the crisis dummies based on estimation equation (4). It must be noted that the estimation model does not include the twin crisis dummies. The bottom half of the table displays significant autoregressive estimates only for the (weighted) twin crisis dummies. The estimates on the (weighted) twin crisis dummies should be regarded as the marginal effect of past twin crises because the estimation model controls for the (weighted) autoregressive crisis dummies (though the estimates are not reported). Because there is no debt crisis episode for the industrialized countries in the sample, the estimate of the debt crisis or the estimates of currency and debt or banking and debt twin crises are unavailable for the group of industrialized countries. 


\section{Table 6: Effects of Past Output Losses on the Degree of Trilemma Policy Divergence}

\begin{tabular}{|c|c|c|c|c|c|c|c|c|c|c|}
\hline \multicolumn{11}{|l|}{ Singular effect of Crisis } \\
\hline Full & $t-1$ & $t-2$ & $t-3$ & $t-4$ & $t-5$ & $t-6$ & $t-7$ & $t-8$ & $t-9$ & $t-10$ \\
\hline Currency & & -0.081 & & & -0.044 & & & & & \\
\hline \multicolumn{11}{|l|}{ Banking } \\
\hline \multicolumn{11}{|l|}{ Debt } \\
\hline Developing countries & $t-1$ & $t-2$ & $t-3$ & $t-4$ & $t-5$ & $t-6$ & $t-7$ & $t-8$ & $t-9$ & $t-10$ \\
\hline Currency & 0.039 & -0.080 & & & -0.080 & & & & & \\
\hline \multicolumn{11}{|l|}{ Banking } \\
\hline \multicolumn{11}{|l|}{ Debt } \\
\hline Emerging markets & $t-1$ & $t-2$ & $t-3$ & $t-4$ & $t-5$ & $t-6$ & $t-7$ & $t-8$ & $t-9$ & $t-10$ \\
\hline Currency & & -0.072 & & & -0.084 & & & & -0.119 & \\
\hline Banking & & & & & & & & & 0.125 & \\
\hline \multicolumn{11}{|l|}{ Debt } \\
\hline \multicolumn{11}{|c|}{ Twin Crises ('Marginal' Effects) } \\
\hline Full & $t-1$ & $t-2$ & $t-3$ & $t-4$ & $t-5$ & $t-6$ & $t-7$ & $t-8$ & $t-9$ & $t-10$ \\
\hline Currency \& Banking & & & -0.082 & & & & & & & \\
\hline Currency \& Debt & & & & -0.071 & & & 0.161 & & & \\
\hline Banking \& Debt & & & & & & & & & & \\
\hline Developing countries & $t-1$ & $t-2$ & $t-3$ & $t-4$ & $t-5$ & $t-6$ & $t-7$ & $t-8$ & $t-9$ & $t-10$ \\
\hline Currency \& Banking & & -0.076 & -0.114 & & & & -0.111 & & & \\
\hline Currency \& Debt & & & & -0.083 & & & 0.191 & & & \\
\hline Banking \& Debt & & & & 0.089 & & & & & & \\
\hline Emerging markets & $t-1$ & $t-2$ & $t-3$ & $t-4$ & $t-5$ & $t-6$ & $t-7$ & $t-8$ & $t-9$ & $t-10$ \\
\hline Currency \& Banking & & & -0.118 & & -0.190 & & -0.217 & & & \\
\hline Currency \& Debt & & & & -0.123 & & & 0.229 & & & \\
\hline Banking \& Debt & & & & 0.205 & & & & & & \\
\hline
\end{tabular}

Notes: The upper half of the table reports only the significant autoregressive estimates for the weighted dummies for crises with output losses. It must be noted that the estimation model does not include the dummies for twin crises with output losses. The bottom half of the table displays significant autoregressive estimates only for the dummies for twin crises with output losses. Because the estimation model controls for the (weighted) autoregressive dummies for the crises with output losses (though not reported), the estimates on the dummies for twin crises with output losses should be regarded as the marginal effect of past twin crises with output losses. 
Figure 1: Average of the Measure of Relative policy divergence over Currency Crisis

(a) Total

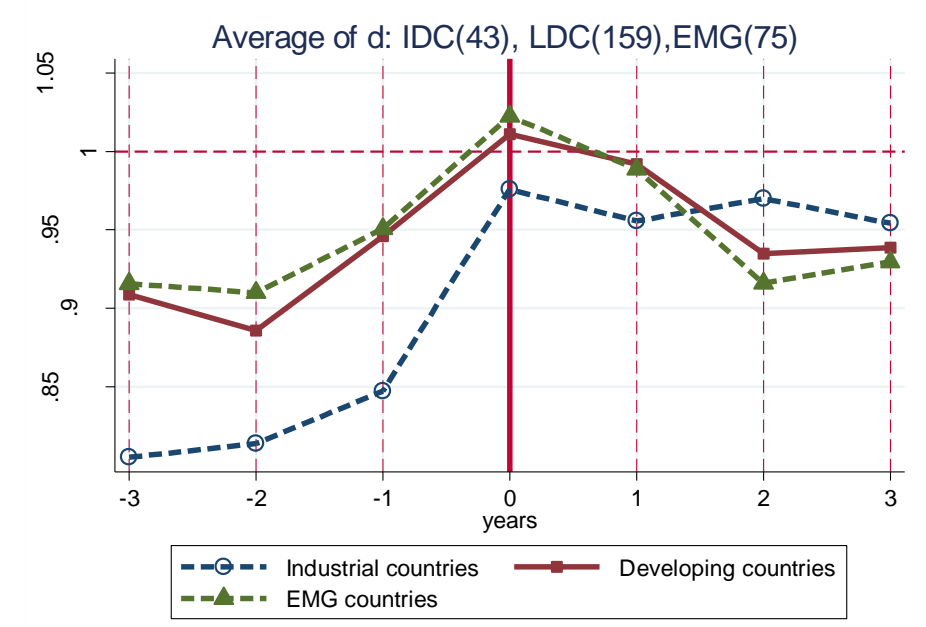

(b) With Output Loss

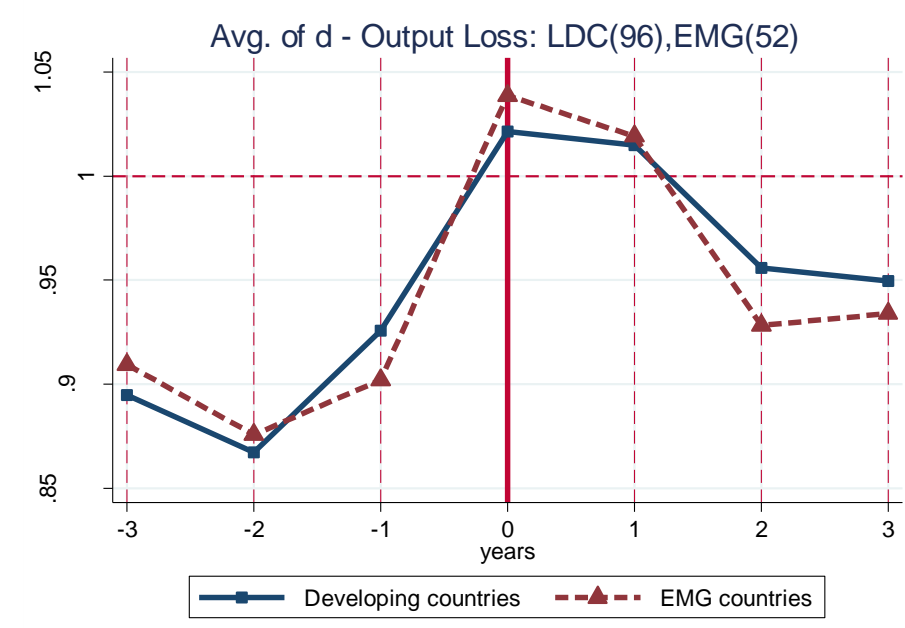

(c) Without Output Loss

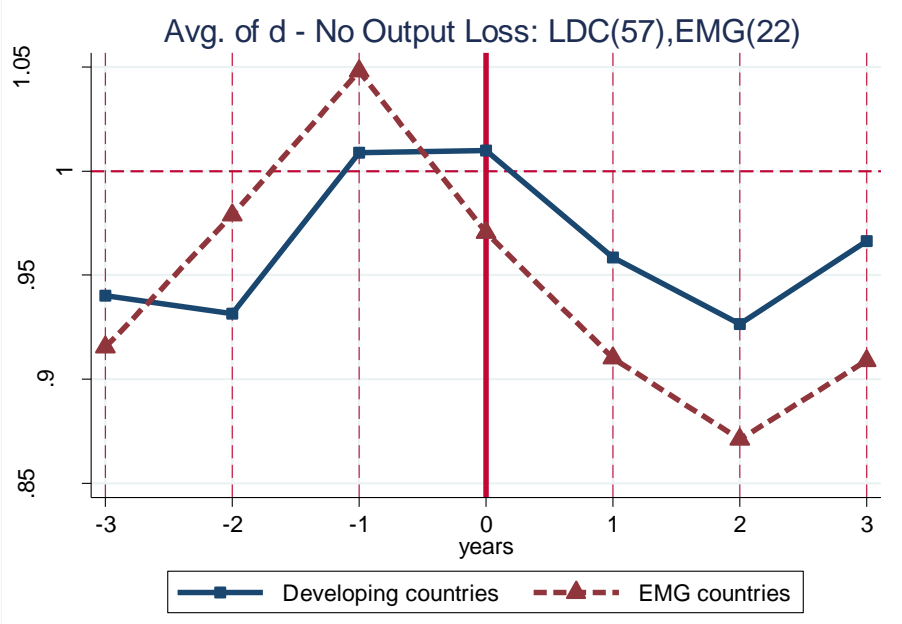

Note: The figures in parentheses indicate the number of countries included in the averaging. 


\section{Figure 2: Average of the Measure of Relative policy divergence over Banking Crisis}

(a) Total

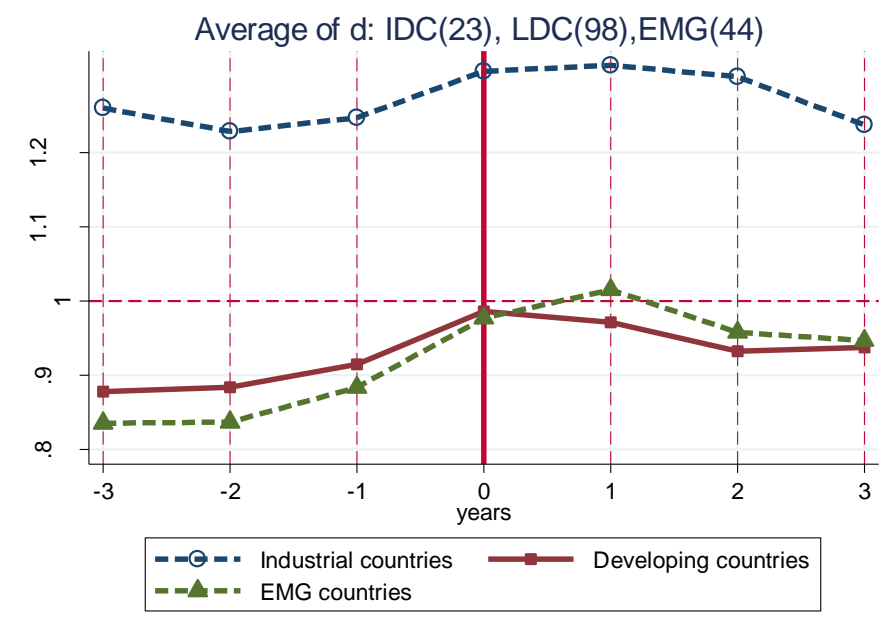

(b) With Output Loss

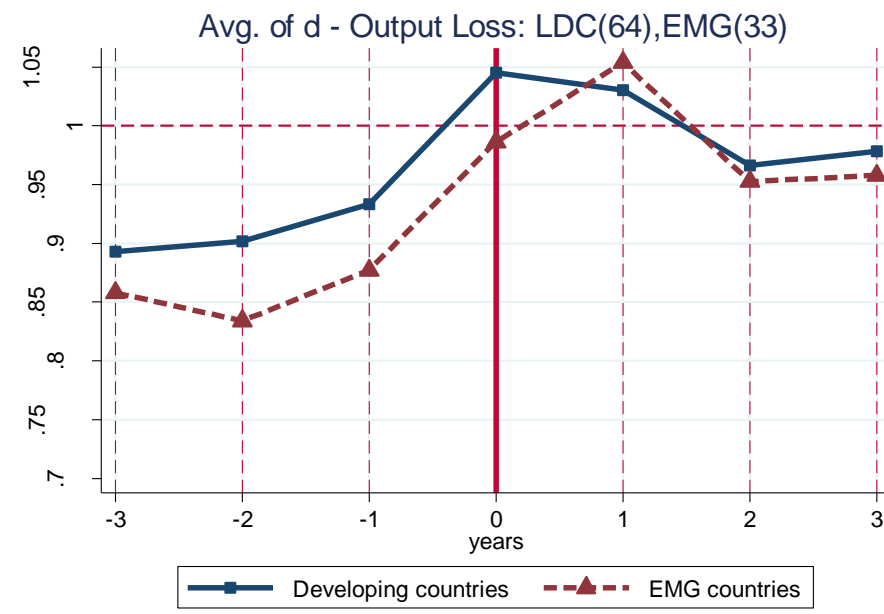

(c) Without Output Loss

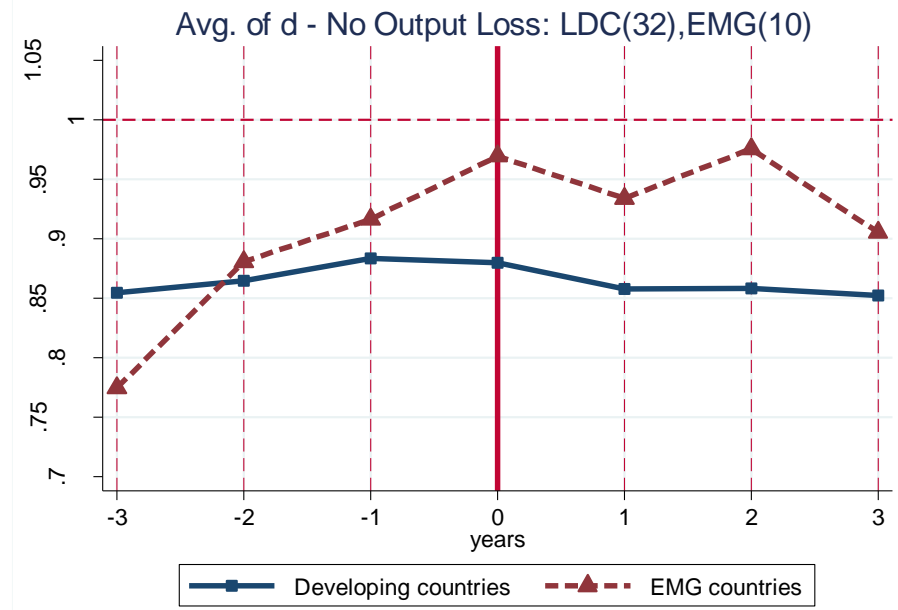

Note: The figures in parentheses indicate the number of countries included in the averaging. 
Figure 3: Average of the Measure of Relative policy divergence over Debt Crisis

(a) Total

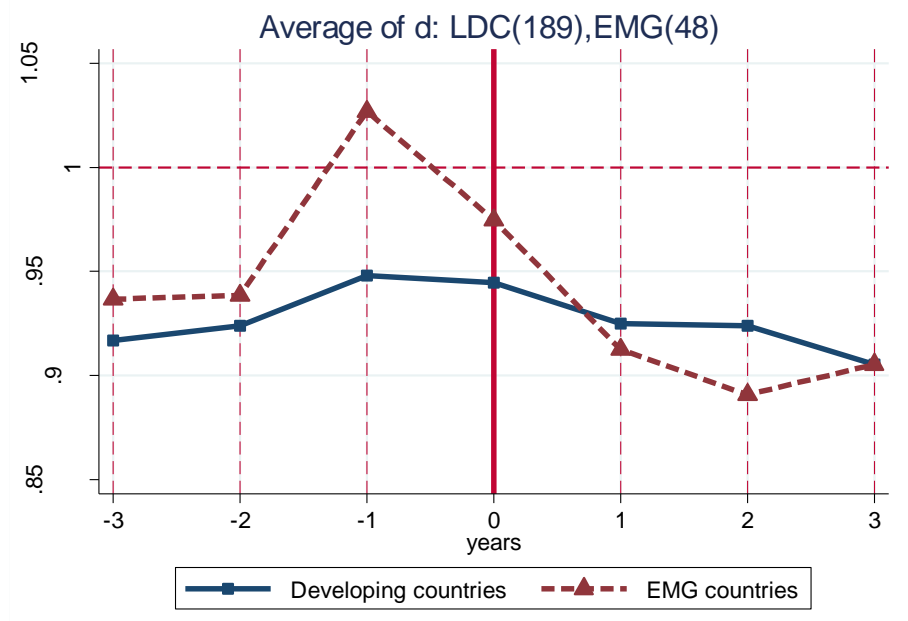

(b) With Output Loss

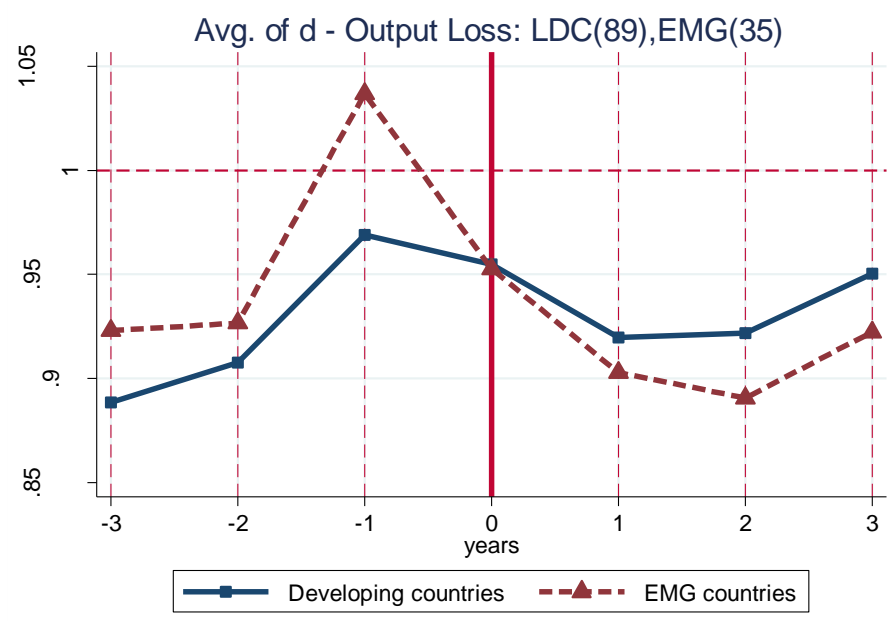

(c) Without Output Loss

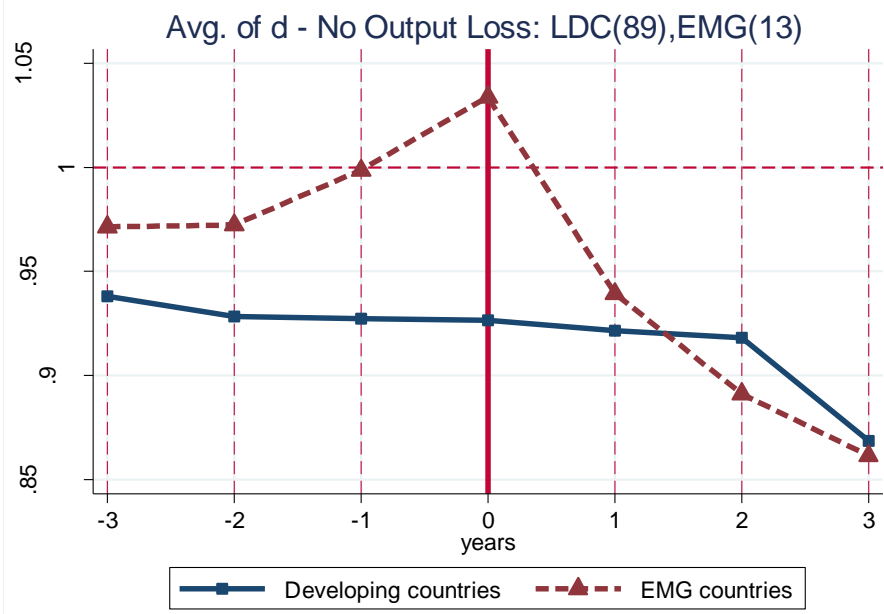

Note: The figures in parentheses indicate the number of countries included in the averaging. 
Figure 4: Average Deviations from the Means for Each Trilemma Index over Currency Crisis

(a) Crises with output losses
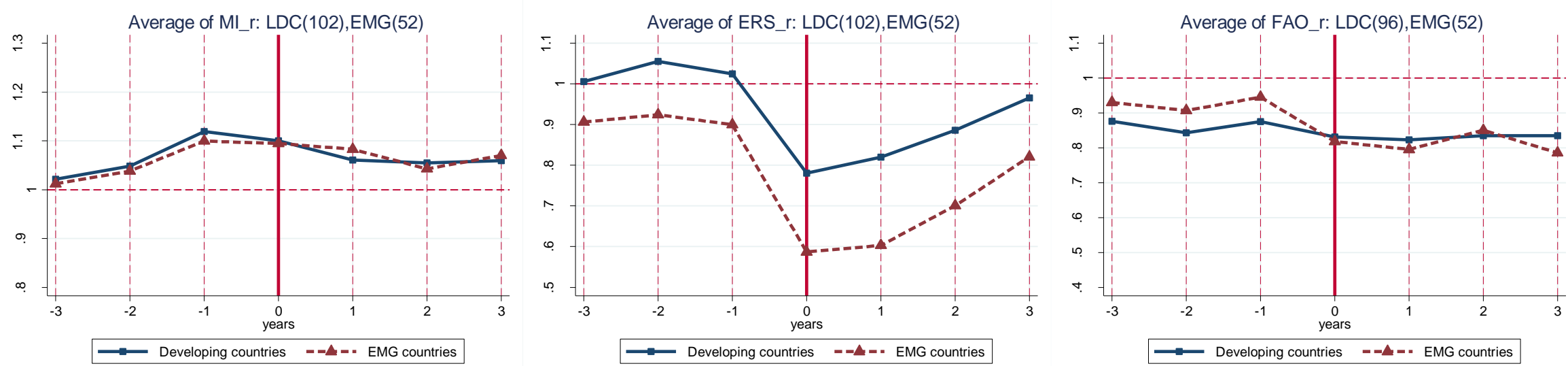

(b) Those without output losses
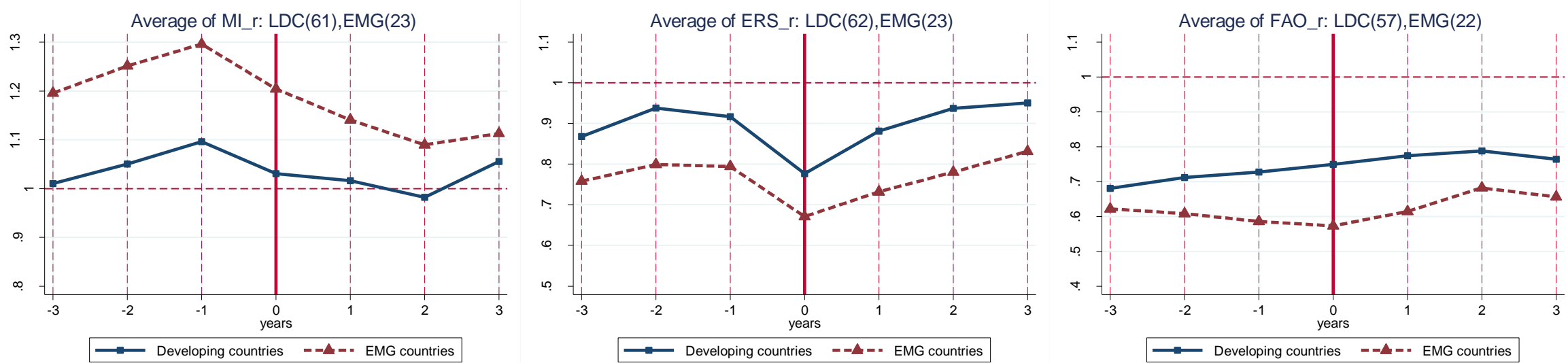


\section{Figure 5: Average Deviations from the Means for Each Trilemma Index over Banking Crisis}

(a) Crises with output losses
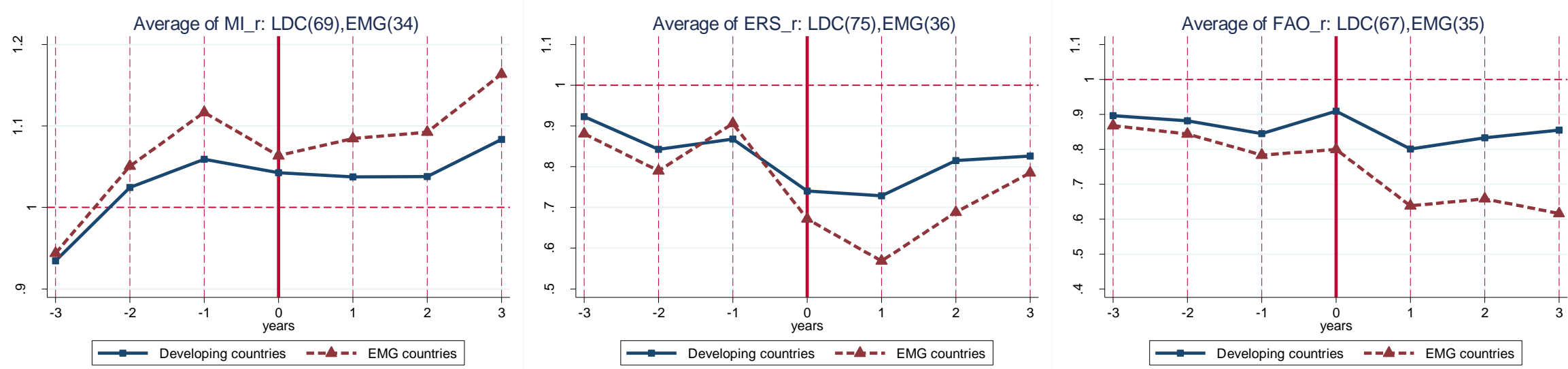

(b) Those without output losses
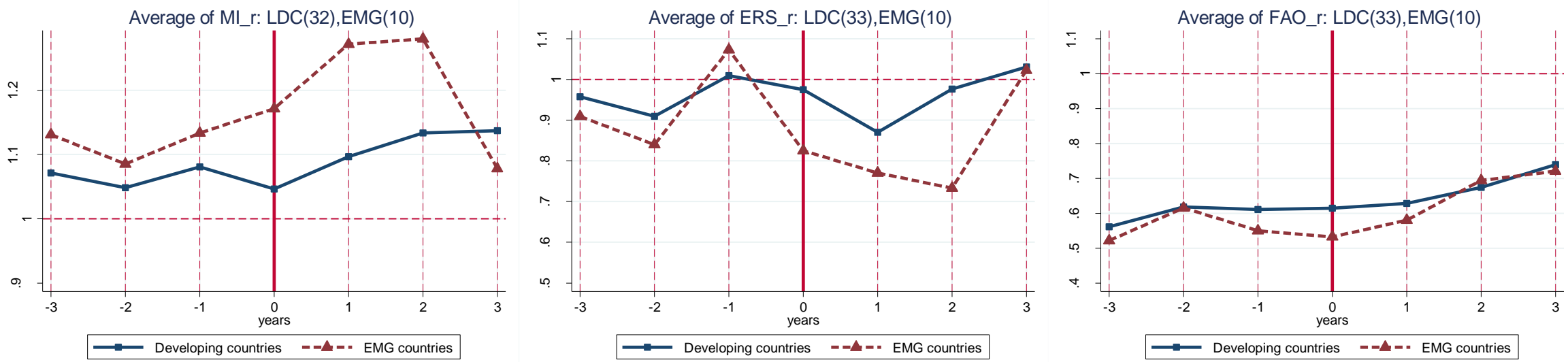